\title{
Het ontstaan van de koude oorlog en de verschuiving van het historisch perspectief *
}

\author{
H.W. VON DER DUNK
}

Wie over het ontstaan van de koude oorlog spreekt, moet beginnen met een sordino op te zetten. De geschiedschrijving over dit onderwerp balanceert tot nog toe op één been. Het gepubliceerde materiaal, al mag het dan voldoende zijn om er een seizoen mee op Schiermonnikoog door te brengen, blijft fragmentarisch. Bovendien betreft het vrijwel uitsluitend materiaal, dat ons inzage verleent in de politiek van het Westen ${ }^{1}$. Elke dieper gaande analyse van de politiek van de Sovjet-Unie is daarom nog meer een kwestie van astrologie dan van geschiedwetenschap ${ }^{2}$. Wie

* Lezing gehouden op de jaarvergadering van het N.H.G. op 24 oktober 1969.

1. Allereerst is er een uitgebreide memoirenliteratuur, waarvan hier slechts te noemen zijn van de hoofdfiguren de memoires van w. CHURCHILL, The Second World War (London, 1948-52); CORDELL HULL, Memoirs, 2 dln (New York, 1948); HARRY S. TRUMAN, Memoirs by Harry S. Truman (New York, 1955); j. BYRNES, Speaking Frankly (New York, 1947); EDWARD R. STETTINIUS, Roosevelt and the Russians (New York, 1949); WILLIAM LEAHY, I was there (New York, 1950); ANTHONY EDEN, The Reckoning. The memoirs of Anthony Eden (Boston, 1965); DWIGHT D. EISENHOWER, Crusade in Europe (Garden City - New York, 1948); HENRY S. STIMSON, On Active Service in Peace and War (New York, 1948) en de nagelaten papieren van Hopkins in R. SHERWOOD, Roosevelt and Hopkins, an Intimate History (New York, 1948) en Forrestal in The Forrestal Diaries, ed. WALTER MILLES/E. S. DUFFIELD (New York 1951). Voorts is er de monumentale serie Foreign Relations of the United States (Washington, 1861-) om slechts enkele voorbeelden te noemen, evenals de redevoeringen van Roosevelt, The Public Papers and Addresses of Franklin Delano Roosevelt (New York, 1950).

2. Pas in het kader van Chroestsjows coexistentiepolitiek begon de S.U. met het publiceren van documenten. Zo verscheen in 1957 een Russische uitgave van de oorlogscorrespondentie tussen de drie oorlogsleiders, waarvan een Duitse editie Briefwechsel Stalins mit Churchill, Attlee, Roosevelt und Truman 1941-1945 (Ost-Berlin, 1961). In 1961 volgde een uitgave van documenten van de conferenties van Teheran, Jalta en Potsdam, door mij gebruikt in de kritisch becommentarieerde uitgave: A. FISCHER ed., Teheran, Jalta, Potsdam. Die Sowjetischen Protokolle von den Kriegskonferenzen der Grossen Drei (Köln, 1968). Deze publicatie was bedoeld als tegenzet tegen de Amerikaanse uitgave The Conferences at Cairo and Teheran (Foreign Relations 1943).

De Russische protokollen van de besprekingen zijn in sommige opzichten gedetailleerder dan de Amerikaanse zogenaamde 'Bohlen minutes'. De uitgevers zijn echter zeer selectief te werk gegaan zonder hun selectie nader te motiveren. Ook ontbreekt een annotatie en notenapparaat, dat beantwoordt aan de eisen, die aan een wetenschappelijk verantwoorde editie mogen worden gesteld, in tegenstelling tot genoemde uitgave vanwege het State Department. Enkele geschilpunten zijn afgezwakt, blijkbaar om een geest van samenwerking op te roepen, in contrast met de latere koude oorlogssfeer. Stalin wordt ook veel meer tot een tegenstander van een verdeling van Duitsland gemaakt, door weglating van betreffende passages, dan hij in werkehjkheid was. (Vgl. de inleiding van A. FISCHER, p. 9). 
hieruit afleidt, dat dan ook nog geen geschiedschrijving over deze periode mogelijk is, begaat dezelfde fout als de goede Palmström bij Christian Morgenstern, die op een wandelpad door een auto wordt overreden en tot de conclusie komt, dat hij gedroomd moet hebben: 'Weil, so schliesst er messerscharf, nicht sein kann, was nicht sein darf.'

Historische beeldvorming ontstaat onmiddellijk, is neerslag van de politieke actualiteit, ja is een voorwaarde tot politiek handelen, of we willen of niet. Die beeldvorming ondergaat dan telkens correcties, maar één blik op uitgebreide discussies in de historiografie laat ook zien, dat in veruit de meeste gevallen niet het nieuwe materiaal de oorzaak van de correcties is, maar de nieuwe bril, die de historicus 'opzet', mag ik niet zeggen: 'opgezet krijgt', door zijn tijd.

Het nieuwe perspectief van waaruit de laatste jaren het begin van de koude oorlog - grofweg de jaren 1945-47 - is bestudeerd, moet vrijwel uitsluitend toegeschreven worden aan zo'n nieuwe bril. Dezelfde bronnen, die voor het allergrootste deel de basis vormen, waren al langer bekend en schraagden ook de oudere voorstelling van zaken. Vandaar dat een confrontatie van de recentere opvattingen met de traditionele niet enkel ons inzicht verdiept in het ontstaan van de koude oorlog, maar ons ook opnieuw ertoe aanspoort om ons rekenschap te geven van onze eigen standplaats en vooral van de drijfveren, die achter onze historische belangstelling liggen.

De tijd waarover het gaat, ligt nog zo goed in ons geheugen, dat ik hier met een summiere schets van de hoofdlijnen kan volstaan.

Het was Walter Lippmann, die in 1947 een boek publiceerde, getiteld The Cold War $^{3}$, een formule, die op slag door iedereen werd begrepen en overgenomen. Bewijs dit laatste, dat Lippmanns vondst kernachtig een toestand karakteriseerde, waar in het historische arsenaal nog geen passende terminus voor bestond. Het Westen aan de ene kant, aangevoerd door de Verenigde Staten, Oost-Europa aan de andere, beheerst door de Sovjet-Unie, bevonden zich in een machtspolitieke en ideologische strijd gewikkeld, die alle kenmerken van een totale oorlog vertoonde. Het enige wat ontbrak, was het openlijke gewapende conflict, waar beide kampen voor terugdeinsden, of nóg voor terugdeinsden, want de hete oorlog lag potentieel in de koude besloten als de vogel in het ei. Helemaal nieuw was Lippmanns term trouwens niet. Al vóór de oorlog werd hij gebezigd om de subversieve activiteiten van de communistische partijen mee aan te duiden. En het betrof nu, in 1947, dezelfde tegenstander.

Afgezien van communisten en enkele onaangepaste buitenspelers, bestond er een communis opinio in het Westen over de aard en oorsprong van die dodelijke conflictsituatie. Terwijl de geallieerden en hun bondgenoten na de oorlog een

3. WALTER LIPPMANN, The Cold War (New York, 1947). 
nieuwe vreedzame en vrije ordening hadden nagestreefd, gebaseerd op de beginselen van het Atlantisch Handvest, die bij allerlei latere gelegenheden waren herhaald of bevestigd, had de Sovjet-Unie deze plannen voor een betere wereld gesaboteerd. Zij had de samenwerking uit de oorlogsdagen verbroken, had een democratische ontwikkeling in de landen, die het Rode leger had bezet, de kop ingedrukt en een expansieve machtspolitiek gevoerd. Doel van dit infame optreden kon slechts zijn, de Westelijke posities zo veel mogelijk te ondermijnen en Europa rijp te maken voor onderwerping. Het Westen was daarbij zo naïef geweest, om ook na de oorlog nog langere tijd op een betere samenwerking te hopen, hoewel de moeilijkheden al waren begonnen, voordat de inkt van de Duitse capitulatieakte was opgedroogd. Amerika bleef op grote schaal ontwapenen en leek zich op een volledig terugtrekken uit Europa voor te bereiden. Pas langzamerhand groeide het besef aan weerskanten van de oceaan, dat het Kremlin van die politiek slechts profiteerde om met meer succes aan de verwezenlijking van zijn imperialistische doelstellingen te werken. Het Westen begon zich dus te weer te stellen tegen de nieuwe totalitaire bedreiging, die nog ernstiger was dan die van het zojuist overwonnen Nationaal-socialisme. Die fatale analogie werd door tal van factoren onderstreept. Niet in het minst door het feit, dat het juist de oude Churchill was, symbool van de strijd tegen Hitler, die in maart 1946 in Fulton zijn waarschuwende stem verhief. Opnieuw leek hij de Cassandrarol voor de beschaafde wereld te moeten spelen. De containment-strategie, die George F. Kennan in diezelfde dagen aan het State-Department voorlegde ${ }^{4}$, het krachtige beleid van Lucius Clay in Duitsland, die voor de Russische uitdaging niet uit de weg ging, en dan vooral de afkondiging van de Trumandoctrine en van de Marshallhulp (1947); de onverzettelijkheid in Berlijn (1948) en tenslotte de oprichting van de NATO (1949), . . ziedaar de belangrijkste stappen op een weg, die aantoonde, dat het Westen van zijn illusies begon te genezen en zich aangordde, opnieuw aangordde, om zijn kultuur en tradities te verdedigen. De koude oorlog was het resultaat van dit

Westerse antwoord op de provocatie van het Kremlin. Het alternatief zou een politiek van appeasement zijn geweest: het meest onbehoorlijke woord uit het naoorlogse vocabularium. Het ene München zou gevolgd zijn op het andere. Aldus globaal de voorstelling, die al spoedig na de oorlog opkwam en die tot in de jaren zestig onbetwist domineerde.

4. Vgl. GEORGE F. KENNAN, Memoirs (London, 1967) 270. Het beroemd geworden artikel van Mr. X., waarin Kennan zijn containment-strategie ontwerpt, verscheen in het juli-nummer van Foreign Affairs (1947). In februari 1946 echter ontwikkelde Kennan dezelfde denkbeelden in een telegram aan het State Department, zodat in feite al een jaar voor publicatie van de containment-gedachte, deze in Washington bekend was. Zie ook L. HALLE, The Cold War as History (London, 1967), die Kennans telegram begroet als basis van een buitenlands beleid, waar in Washington zo'n grote behoefte aan bestond. De publieke opinie was in 1946 echter nog lang niet rijp voor deze ideeën, meent Halle. Pas een jaar later kon men daarmee voor de dag komen. 
Het is daarom zinvol om nog even na te gaan hoe dit beeld was ontstaan en waarop het was gebaseerd. Een gevoel van onveiligheid en angst, dat zo snel en zo penetrant om zich heen grijpt, komt niet uit de hemel vallen. Zeker niet na een katastrofe, die iedereen naar rust en vrede deed verlangen om zijn wonden te likken.

Vooropgesteld dient dan te worden, dat bij het grote publiek tijdens de oorlog een wat wonderlijke mengeling van de wil naar vernieuwing en de wens naar herstel van de status-quo-ante leefde. De laatste resulterend uit de natuurlijke traagheid van het voorstellingsvermogen. Maar de grenzen van 1937 golden als legitiem, evenals de oude regeringen. Hoogstens met Duitsland zou er iets drastisch moeten gebeuren om deze haard van agressie uit te roeien. Winston Churchill en de Britse regering voerden de strijd stellig niet voor een nieuw Europa, maar voor herstel van het oude. Al spoedig werd echter duidelijk, dat Engeland steeds meer in het kielzog van Amerika geraakte. En evenals tijdens de eerste wereldoorlog richtten zich daarmee de blikken van allen, die de klok niet meer terug wilden zetten, die sociale en politieke vernieuwingen wensten en die in een nieuwe betere toekomst wilden geloven, naar de overzijde van de oceaan. En evenals destijds in Wilson vonden zij opnieuw een president, die dat verlangen naar een betere samenleving en het geloof in de vooruitgang symboliseerde. Ja, met zijn charme en optimisme sprak Roosevelt nog meer tot de verbeelding dan de stijve schoolmeester Wilson.

Voor Roosevelt, Cordell Hull en de Amerikanen immers was het evident, dat het oude Europese systeem had gefaald en vervangen diende te worden door een mondiaal veiligheidsstelsel. En niet enkel de Europese machtspolitiek maar ook het kolonialisme moest geliquideerd worden; de kans kortom, die Wilson niet had kunnen grijpen was opnieuw gekomen '... to make the world safe for democracy.' In het Atlantisch Handvest ${ }^{5}$ en in de andere gemeenschappelijke beginselverklaringen van de Grote Drie werd het beeld opgeroepen van een nieuwe harmonieuze wereldorde, gebaseerd op Roosevelts blijde boodschap van de vier vrijheden. Niet alleen Engeland maar ook de Sovjet-Unie had, zo leek het, haar adhesie betuigd $^{6}$. Dit alles gecombineerd met de onderbewuste verwachting van het herstel van de staatkundige Europese status-quo-ante moet verdisconteerd worden om het effect te begrijpen van de gebeurtenissen, die zich tegen het einde van de oorlog voltrokken en die in de volgende jaren tot de koude oorlog voerden.

Waar het Rode Leger verscheen werden communisten in kernposities geplaatst. Elementen, die de Russen niet zinden, werden uitgeschakeld. De exielregeringen,

5. De tekst van het A.H. gepubliceerd in Churchill, Second World War, III, 393.

6. Vgl. vooral het slotcommuniqué van Jalta Foreign Relations. The Conferences at Malta and Jalta, 531 evenals Roosevelts boodschap aan het congres van 1 maart in zijn Public Papers and Addresses, II, 570. 
die door het Westen als legitiem werden beschouwd, leken te worden weggewerkt of werden drastisch gemodelleerd. Vrije verkiezingen, door de Sovjet-Unie te Jalta voor Oost-Europa toegezegd, bleken nu meer en meer te betekenen: eerst liquidatie van alle krachten, die een bedreiging vormden voor de heerschappij van wat Moskou de werkende klasse noemde. Democratie moest worden vertaald in: democratie voor allen minus allen, die rechts van het linker centrum stonden. Dit Russische optreden kwam al als een rauwe ontnuchtering na de euforie van het bondgenootschap, door gemeenschappelijke verklaringen nog aangewakkerd. Maar er kwam nog iets bij, dat de bevolkingen in het Westen een koude rug bezorgde: de indruk, die de macht van het Rode leger maakte, dat ineens midden in Europa stond. Het gevoel dat, wanneer de Amerikanen zich eenmaal terug zouden trekken, hetgeen algemeen werd verwacht, een economisch ontredderd en militair hulpeloos West-Europa een gemakkelijke prooi voor de Russische tanks zou worden. Psychologisch is het niet verwonderlijk, dat men zich-met de kaart met de beangstigende getallen van de Russische divisies en het akelig smalle strookje, dat hen van de Noordzee scheidde, voor ogen - op het ergste voorbereidde en instelde op een tegenstander, die niet zou rusten, alvorens het hele continent te hebben onderworpen. Daarbij herinnerde men zich onmiddellijk weer de marxistisch-leninistische leer. Daar werd het niet onder stoelen of banken gestoken: einddoel van de geschiedenis was de vernietiging van het kapitalisme. En machtige communistische partijen in Frankrijk, in Italië, stonden klaar, om van binnen uit het Westen rijp te maken voor het grote uur. De schaduw van Stalin viel zwaar over het hele continent, dat nog nauwelijks was bekomen van de terreur van de nazis. En hier ligt stellig nóg een belangrijke factor, die de stemming beïnvloedde: de analogie tussen Rusland en nazi-Duitsland, tussen het ene totalitaire systeem en het andere. Analogieën vormen een pièce de resistance van alle politieke denken en vooral ook van politieke argumenten. Men wilde en kon de les uit de jaren dertig niet vergeten, toen een zwak Westen een dictator alsmaar concessies had gedaan en daarmee diens honger en brutaliteit slechts had vergroot.

De fouten, die het Westen bij de behandeling van Hitler gemaakt had, wilde het bij de behandeling van Stalin niet herhalen. De jaren veertig en vijftig stonden daarmee nog in de schaduw van de jaren dertig.

De geschiedschrijving schetste de koude oorlog dan ook ondubbelzinnig vanuit deze achtergrond. De opvattingen liepen uiteen hoogstens bij de vraag óf en hoe het Westen de machtsaanwas van Sovjet-Rusland tijdiger had kunnen afremmen. Er was een tegenstelling tussen de auteurs, die de dwangpositie beklemtoonden, waarin de staatslieden van het Westen zich hadden bevonden ${ }^{7}$ en hen, die be-

7. Edward Stettinius, Roosevelt and the Russians stelt met klem, dat de president geen enkel vitaal belang te Jalta of elders heeft opgeofferd. Het zijn vooral de politici uit Roosevelts 
weerden, dat het heel anders had kunnen lopen, als men minder toegevend of illusionistisch had gehandeld ${ }^{8}$.

Centraal in dit opzicht stond om voor de hand liggende redenen de figuur van Roosevelt. Hij was de grote pleiter van samenwerking met Rusland geweest in de hoop, de Sovjets voor zijn wereldorde te kunnen winnen; hij werd daarom nu in brede kringen bovenal aansprakelijk gesteld voor het grote fiasco. Men verweet hem, dat hij uit naïef illusionisme onnodige concessies aan de Sovjet-Unie had gedaan, waarbij men bovenal aan Oost-Europa dacht. En tegenover de onrealistische, zorgeloze president en zijn adviseurs, stegen de papieren van die politici, die voor de bedoelingen van het Kremlin hadden gewaarschuwd en die in een vroeg stadium op indamming van de Russische macht waren uitgeweest; voorop Winston Churchill. In dit verband werd altijd weer verwezen naar diens hardnekkig pleidooi voor militaire operaties in de Balkan, of het Britse plan om in de herfst 1944 Montgomery direct door te laten stoten naar het Ruhrgebied in Oostelijke richting, liefst tot Berlijn; een plan, dat op het vierkante Amerikaanse veto afstuitte ${ }^{9}$.

De gepubliceerde stukken over de oorlogsdiplomatie en met name over de conferenties van de Grote Drie bevestigen inderdaad, dat het Churchill was, die zich als de uitgesproken opponent en tegenvoeter van Stalin ontpopte. Roosevelt nam welbewust bij allerlei conflicten een tussenpositie in, ja hij was er duidelijk op uit Stalin te paaien door zijn geschilpunten met Churchill openlijk wat op te blazen, waarbij hij graag buiten de Prime Minister om zaken met de Rode dictator $\operatorname{deed}^{10}$. De ironie wil, dat die door Roosevelt destijds om tactische redenen aan-

regering, die zelf bij de gebeurtenissen waren betrokken, die de dwangmatigheid van de ontwikkeling of de trouweloosheid van de Russen onderstrepen, terwijl de historici zich kritischer opstelden. Maar ook HARDY MAC NEILL laat in zijn rijk gedocumenteerde en genuanceerde studie America, Britain and Russia 1941-45 (Survey of International Affairs, V, London, 1953) de moeilijkheden uitkomen, waarvoor de staatslieden stonden, hetgeen vanzelf een scherpe kritiek op Roosevelt bemoeilijkt, HERBERT FEIS, zelf regeringsfunctionaris, wil in zijn boek Churchill, Roosevelt, Stalin (Princeton, 1957) o.a. laten uitkomen, dat Roosevelt na Jalta van zijn 'illusies' begon te genezen en al naar de koers van Trumans regering ging overhellen.

8. De voorstelling van een zwak toegeeflijk Westen, dat in Jalta voor Stalin door de knieën ging, werd al door de Goebbelspropaganda gelanceerd. Het felst zijn de verwijten van 'verraad' uiteraard bij Oost-Europese en Duitse auteurs. Vgl. J. CIECHANOWSKI, Vergeblicher Sieg (Zürich, 1948), s. MIKOLAJZYK, Verkracht volk in de greep van Rusland (Bilthoven, 1949). In de Angelsaksische literatuur zie J. w. SPANIER, American Foreign Policy since World War II (New York, 1960), w. H. CHAMBERLIN, America's Second Crusade (New York, 1952), IOHN SNELL e.a., The Meaning of Jalta (Baton Rouge, Louisiana Un. Pr., 1956), J. LUKACS, New History of the Cold War (New York, 1966).

9. Vgl. CHESTER WILMOT, 458-476.

10. Foreign Relations, The Conferences at Cairo and Teheran, 483, 529; The Conferences at Malta and Jalta, 572, 766. Ook Teheran, Jalta, Potsdam, ed. A. FISCHER, 20. Het befaamde geheime akkoord over het verre Oosten in Jalta kwam buiten Churchill om tussen Roosevelt en Stalin tot stand, al heeft de Prime Minister het wel mede ondertekend. 
gedikte controverses met Churchill door zijn latere critici nu juist werden uitgespeeld tégen hem, terwijl Churchill zelf altijd de overeenstemming in de essentialia beklemtoonde.

De felle kritiek op Roosevelt in de V.S. werd natuurlijk nog uit geheel andere bodem gevoed en had haar zeer interne partijpolitieke en psychologische wortels. Het beeld van de grote illusionist, die zich zo fataal verkeken had op de ware natuur van Rusland bleef ook stellig niet onweersproken in de literatuur. Maar ook zij, die het voor Roosevelt opnamen, beweerden allerminst, dat er een werkelijke kans op een duurzame coöperatie met de Sovjet-Unie was geweest. Tegenover de in de jaren vijftig alom vigerende mening, dat het antagonisme tussen het vrije democratische Westen en de Sovjet-Unie onverzoenlijk was, stelden ook zij niet de Rooseveltiaanse idylle van een grote volkerenfamilie. Men kon Roosevelt .tegenover de beschuldigingen alleen verdedigen door op de dwangpositie te wijzen, waarin hij zich had bevonden en op de onvermijdelijkheid van de ontwikkeling. Of men kon zeggen, dat hij in waarheid veel minder illusies had gekoesterd, dan hij om politieke redenen moest doen voorkomen. En men kon in dit verband laten zien, dat al vóór zijn einde ernstige moeilijkheden met de Russen waren begonnen, die ook Roosevelt tot een andere houding brachten ${ }^{11}$. Zijn plotselinge dood alleen versluierde dat.

Een man als Byrnes, die de omschakeling van de Amerikaanse politiek in de eerste na-oorlogsjaren mede uitvoerde, getuigt in zijn memoires van het optimisme, dat tijdens en na Jalta algemeen in het Westerse kamp heerste, ook bij de Engelsen ${ }^{12}$. Pas langzamerhand lieten de Russen in de weken daarna het masker vallen, meent hij. Juist omdat Byrnes niet tot de naaste medewerkers of de grote bewonderaars van Roosevelt behoorde, impliceert zijn voorstelling, dat de president de dingen niet wezenlijk anders zag dan andere toonaangevende politici, die in Jalta aanwezig waren, Churchill inbegrepen. En Churchill zelf geeft in zijn memoires eveneens dat beeld ${ }^{13}$.

Ergo: de Roosevelt van februari 1945 verschilde niet alleen van de Truman van mei 1945, maar hij zou evenzeer verschild hebben van een Roosevelt van mei. Zijn dood betekende slechts uiterlijk een breuk. Maar hij heeft niet die veranderingen van beleid veroorzaakt. Die waren eenvoudig het gevolg van de nieuwe Russische houding. Tot zover Byrnes, die in dit opzicht ook door de memoires van Truman wordt gesteund, waarin eveneens een bewuste breuk in de democratische politiek wordt ontkend ${ }^{14}$.

11. Vgl. Feis a.w. en A. SCHLESINGER, 'Origins of the Cold War', Foreign Affairs, Okt. 1967. Schl. wijst er op, dat Roosevelt zwaar gebelgd was over de Russische houding na Jalta, al hield hij zijn wrevel binnenskamers.

12. J. BYRNES, Speaking Frankly, 21.

13. CHURCHILL, VI, 350. Ook SHERWOOD, a.w., 870.

14. HARRY s. TRUMAN, 1945 Year of decisions. Memoirs by H. S. Truman. 


\section{H. W. VON DER DUNK}

Tegenover de these van een a priori anti-kapitalistisch aggressief Rusland, dat tijdig had moeten en kunnen worden bestreden, die vooral in republikeinse kringen veel aanhangers vond, legden vele democraten of figuren, die een politieke rol hadden gespeeld onder Roosevelt, zo het accent op de grote veranderingen in de Russische houding na Jalta en op het Russische 'verraad' aan de gemeenschappelijke beginselen, waarvoor tenslotte niet wijlen Roosevelt en de Democraten verantwoordelijk konden worden gesteld.

Toch waren er ook in de dagen van de verraadspsychose, toen McCarthy zijn onzalige rol speelde, die aan Roosevelts coöperatie-idee bleven geloven, zoals Henry Wallace. Voor hem betekende de dood van de president terdege het einde van hoopvolle toekomstperspectieven. In de politiek van de Trumanadministratie vermocht hij dan ook geen koerswijziging te zien, die uitsluitend of in de eerste plaats door de Russische houding was afgedwongen ${ }^{15}$. Maar Wallace en geestverwanten vormden een kleine minderheid. De bewapeningswedloop, die in de jaren vijftig steeds dreigender vormen aannam, het besef, dat de koude oorlog plotseling uit de hand zou kunnen lopen en in een hete oorlog zou omslaan, die nu ook voor Amerika zelf atomaire vernietiging betekende, dat waren inmiddels realiteiten, die een uitweg uit de impasse steeds dringender maakten. En de kruistochtideologie, het zwart-wit-schematisme, dat door Foster Dulles werd gekultiveerd, blokkeerde zo'n uitweg, onder het refrein: 'hier staat Amerika, het kan niet anders, God helpe ons, het Communisme is schuld!' Toen zich tijdens het bewind van Kennedy, de kentering in het antagonisme na de Cubacrisis voltrok, won het verlangen en ook de hoop om de vicieuze cirkel te doorbreken aan kracht. In dit verlangen schuilt de ene wortel van een nieuwe benadering van de koude oorlog; een wortel, die teruggaat naar de jaren vijftig en naar de oppositie tegen de theologie van Dulles.

Maar later kwam er nog een belangrijk element bij. Het voorzichtig-kleurloze bewind van Chroestjows opvolgers in buitenlands opzicht contrasteerde steeds meer met het optreden van de Amerikanen in Vietnam. Men kan op goede grond in het anti-amerikanisme van de laatste jaren ook het protest tegen de vader zien; een protest, dat niet toevallig dan ook allereerst het applaus van de jonge generatie vindt. Helemaal klaar zijn we er niet mee. Ook wie vol blijft houden, dat Amerika het goede en Moskou het kwade principe op aarde vertegenwoordigt, zit met het hinderlijke factum, dat het goede blijkbaar tot napalm zijn toevlucht moet nemen, terwijl de duivel zich niet uit de tent laat lokken. Dat stemde tot nadenken. Allereerst in Amerika zelf.

15. Wallace wees Truman er in september 1946 op, dat de Russische houding z.i. te verklaren viel uit hun economische moeilijkheden en het onbegrip, dat van Amerikaanse zijde daarvoor aan de dag was gelegd, TRUMAN, Memoirs, II 552. Ook D. HOROWITZ, From Jalta to Vietnam (2e ed., Penguin Books, 1967). 
Tegen deze achtergrond waren nu twee redenaties voor de historici van de koude oorlog mogelijk: óf beide grote antagonisten zijn sterk veranderd sedert 1945, óf die veranderingen lijken slechts zo groot, omdat de Sovjet-Unie in wezen nooit zo militant en de Verenigde Staten nooit zo idealistisch zijn geweest als men in het Westen dacht. Wie er bovenal op uit is om genetische verbanden te onthullen - en welke historicus komt vandaag zonder die poging uit! - zal uit hoofde van zijn vak gauw tot de laatste hypothese overhellen. Hij zal in het Amerika van 1945 dat van 1965 gaan zoeken en in de Sovjet-Unie eveneens het land van twintig jaar later. Hier ligt een andere wortel van de nieuwe benadering, die wij gemakshalve maar de revisionistische zullen noemen. Evenmin als de traditionele historiografie, die de conflictsituatie tot uitgangspunt koos, is zij daarmee vrij van finalistische boventonen.

Daarbij lopen vraagstelling en aanpak van de revisionisten overigens zeer uitelkaar. Voor D. F. Fleming, The Cold War and its Origins ${ }^{16}$, ligt de oorsprong van de tegenstelling al in de Bolsjewistische revolutie. Dat is niet zo nieuw, want de fundamentele controverse tussen het liberale kapitalisme en het communisme is niet enkel alfa en omega voor de marxistische historiografie, maar ook voor de westelijke theoretici van de koude oorlog; met omkering van de voortekens. Maar Fleming gaat gewoon na, wat de practische gevolgen waren van het ideologische antagonisme en hij keert daarbij de vragen om, door systematisch de antirussische tendenties in de politiek van het Westen, bovenal van Amerika, te beschrijven, ook al in het Interbellum. Hij laat zien, dat de nieuwe Russische leiders zich van begin af geconfronteerd zagen met een Westen, dat hen niets zo van harte toewenste als een spoedig einde en dat het niet bij zuiver platonische gevoelens $\operatorname{liet}^{17}$. We lezen hoe het Russische streven, om in de jaren dertig in de Volkenbond tot een anti-fascistisch front te komen door het Westen werd genegeerd, dat zich

16. D. F. FLEMING, The Cold War and its Origins, 1917-1960, 2 dln (London, 1961). Voor Fleming, die zijn werk in de latere jaren vijftig schreef, ging het bovenal om die boven geschetste poging de impasse van de bewapeningswedloop en de bevroren ideologische instelling te doorbreken. Vietnam was toen nog geen kwestie.

17. Vgl. ook WILLIAM S. GRAVES, America's Siberian Adventure, 1918-1920 (New York, 1941); W. A. WILLIAMS, American-Russian Relations, 1781-1917 (New York, 1952); GEORGE F. KENNAN, Soviet-American Relations, 1917-1920 (Princeton, 1956). Door het belangrijke boek van ARNO J. MAYER, Politics and Diplomacy of Peacemaking. Containment and Counter-Revolution at Versailles, 1918-1919 (London, 1968), is deze hele vraag zeer recentelijk en zeer fundamenteel aan de orde gesteld. De ondertitel is al een aanwijzing, dat Mayer, evenals Fleming in Versailles het begin van de koude oorlog zoekt. Men zou Mayer, al behandelt hij een andere periode en een ander thema, ook bij de revisionisten kunnen rekenen. De rol, die de vrees voor het Bolsjewisme bij de beslissingen in Versailles heeft gespeeld, is in de oudere literatuur stellig te kort gekomen. In die vrees en in de wens om het Bolsjewisme te vernietigen echter de geheime basis van de vredesregeling te zien, lijkt mij een onhoudbare simplificatie. Een simplificatie alweer, die een latere tegenstelling al te dogmatisch terugprojecteert en blind is voor alle elementen, die vandaag misschien geen betekenis meer hebben. 
liever met Hitler wilde verstaan. In de appeasementpolitiek en in München vierde die politiek haar hoogste triomf ${ }^{18}$. Kon men het Stalin euvel duiden, dat hij uit lijfsbehoud zelf dan maar met de gevaarlijke nazidictator tot een accoord kwam? ja, zelfs toen men zich al in oorlog met Duitsland bevond, wond men zich over de Russische aanval op Finland veel meer op, dan over de vernietiging van Polen; een bewijs, dat een anti-russische houding de massa's nog altijd veel gemakkelijker af ging dan een anti-duitse. En de oude aversie stak ook tijdens de oorlogsalliantie telkens achter de schermen de kop op, zoals Fleming duidelijk maakt ${ }^{19}$. Het gedrag en de reacties van de Russen krijgen zo een defensief karakter, omdat zij doorlopend met een muur van onbegrip en vijandigheid werden geconfronteerd. De grote verdienste van dit moedige en onafhankelijke boek is, dat een verhaal, dat in wezen iedereen al kende, in een geheel ander licht verschijnt. Wanneer men zich voor ogen houdt, dat Stalin en de Russische leiders meer dan twintig jaar lang met een uitermate kille Westelijke diplomatie te maken hadden, die vaak in onverhulde vijandigheid uitmondde, dan wordt de Russische vrees voor een Westelijke "Einkreisung' begrijpelijk. Om het diepe wantrouwen van Stalin te verklaren behoeft men niet uitsluitend zijn toevlucht te nemen tot een paranoïde aanleg. Wat hierbij alleen niet mag worden vergeten is, dat dat Westerse gebrek aan warmte en sympathie voor de Russische leiders het antwoord was op hun sedert jaren luidkeels verkondigde totale oorlogsverklaring aan het kapitalistische stelsel. De schuldvraag wordt hier, gelijk zo vaak, een bodemloze put. Bovendien bevatte de politiek van het Westen nog een hele bundeling van andere elementen. Zij kan niet, zoals bij Fleming, uitsluitend geregen worden op dat ene dunne snoer: anti-communisme. Het gebruik van persberichten en redevoeringen, het voorvoornaamste materiaal van Flemings boek, maakt dan ook een eenzijdige indruk. Gehypnotiseerd door de anti-russische tendenties in het Amerikaanse denken en vervuld van een heftige aversie tegen de kruistochtgedachte van Dulles, maakt de historicus meer en meer plaats voor de theoloog, de tegen-Dulles, die een zeer verwante vinger omhoog steekt, alleen een andere kant op. Maar het blijft Flemings verdienste de standaard-benadering nu eens te hebben omgekeerd, zonder daarbij zijn toevlucht te nemen tot het marxistische schematisme.

18. FLEMING, 53. Men heeft in de oudere Westerse literatuur over het algemeen de samenhang tussen München en het Ribbentrop-Molotofverdrag sterk verwaarloosd. Door een (terecht) felle veroordeling van München en een accentuering van de omslag in de politiek van het Westen in 1939 kon men zo al te gemakkelijk tot de conclusie komen, dat het Westen tenslotte zijn fout dan toch maar had hersteld. Met des te grotere verontwaardiging werd dan de machiavellistische Stalin geconfronteerd met dit in 1939 van alle appeasementsmetten gereinigde Westen, dat nu vastbesloten was in zijn strijd tegen Hitler. Daarbij wordt vergeten, dat uit Russisch perspectief München ook een vorm van machiavellisme was en bovenal, dat de vastbeslotenheid om Hitler een halt toe te roepen in 1939 nog allerminst bewezen was en .zeker geen basis vormde voor een Russische politiek.

19. FLEMING, 35. 
Meer diepgang vertonen de studies van William Appleman Williams ${ }^{20}$, die de economische implicaties van de Amerikaanse politiek bloot legt; de constante eis van een mondiale vrijhandel, zoals die al in de 'open-door policy' geformuleerd was. De politieke concepties met hun democratisch-verlicht credo degraderen bij Williams ietwat tot de ideologische verpakking van die economische belangen en wensen. Wanneer dè Amerikanen op de bres stonden voor democratie en zelfbeschikkingsrecht, dan zagen zij daarin ook de beste garantie voor een politiek van de open deur, die de zakenwereld nodig had ${ }^{21}$. Ook het Amerikaanse protest tegen het Russische optreden in Oost-Europa hing ten nauwste samen met de verlangens om dat gebied economisch open te breken en als vrije markt voor de Amerikaanse export toegankelijk te maken. Williams heeft hiermee zonder twijfel een uiterst belangrijk probleem aangesneden: de onlosmakelijke verstrengeling van de Amerikaanse voorstellingen van de natuurlijke democratische ordening met de Amerikaanse economische structuur. Men kan misschien in concrete gevallen aantonen, dat niet die economische motieven domineerden maar de politieke of ideologische, of: men kan het zonder enige twijfel! Daarmee is echter niet de essentie van Williams' these weerlegd: de twee-eenheid van democratie en vrijhandel in de Amerikaanse traditie, die teruggebracht kan worden tot het klassieke liberalisme met zijn bekende janusgodheid: welvaart en vrijheid. Het is duidelijk, dat daarmee ook het ontstaan van de koude oorlog in een ander licht komt te staan, omdat in het Russische optreden een afweer van de expansie van de superieure Amerikaanse economie wordt gezien.

Over weer een andere boeg gooit het Gar Alperovitz ${ }^{22}$. Voor hem staan niet de economische aspecten centraal, maar de politiek-strategische. Hij wil laten zien, dat Amerika door het bezit van de Atoombom in de zomer van 1945 meende de Russen een pax americana te kunnen opleggen. Het bewustzijn van de eigen militaire superioriteit maakte Washington ineens veel minder inschikkelijk, doch eerder geneigd om de vele meningsverschillen en controverses door een show-down met Moskou op te lossen. Het afwerpen van de bommen op Hiroshima en Nagasaki dient niet allereerst te worden gezien als een paardemiddel om Japan snel op de knieën te krijgen, maar als demonstratie van de Amerikaanse macht tegenover Moskou. Anders dan voor Fleming en voor Williams ligt voor Alperovitz de kritieke fase van de breuk dan ook in het jaar 1945 en de lange voorgeschiedenis valt buiten zijn bestek. Dat laatste geldt ook voor David Horowitz ${ }^{23}$. Bij hem speelt de huidige constellatie nog veel duidelijker mee dan bij de anderen. Zijn hele

20. W. A. WILliAmS, The Tragedy of American Diplomacy (2e ed., New York, 1962); id., American-Russian Relations.

21. Vooral: id., Tragedy.

22. GAR ALPEROVITZ, Atomic Diplomacy: Hiroshima and Potsdam (London, 1965).

23. DAVID HOROWITZ, From Jalta to Vietnam (rev. ed., Penguin Books, 1967); id., Containment and Revolution (London, 1967). 
vraagstelling wordt bepaald door zijn afschuw over het bondgenootschap van Amerika met de reactionaire krachten overal ter wereld en vooral in Azië en Zuid-Amerika. Een bondgenootschap, zo in strijd met het Amerikaanse zelfportret! In die contrarevolutionaire impuls ligt voor Horowitz de oorzaak van de koude oorlog.

Een combinatie in zekere zin van deze these en van de hoofdthese van Williams vinden we in het recente dikke boek van Gabriel Kolko ${ }^{24}$. Maar dan gebaseerd op een oneindig veel grotere hoeveelheid materiaal, waaronder vooral zeer veel persoonlijke archieven van vooraanstaande Amerikaanse politici. Kolko ziet als drijvende kracht achter de Amerikaanse politiek al tijdens de oorlog het streven, om de zwaar aangeslagen kapitalistische maatschappij te redden en een wereldwijd vrijhandelssysteem op te bouwen, dat dan vanzelf de hegemonie van het superieure Amerikaanse potentieel zou garanderen. Dat betekende een poging alle conservatieve en zelfs fascistische krachten voor vernietiging te bewaren. Daarbij richtte de politiek van Washington zich bewust tegen drie tegenstanders: de Sovjet-Unie, de verzetsbewegingen, die overal op een sociale vernieuwing uit waren en het Britse Gemenebest, de oude kapitalistische concurrent. Dit laatste, de felle controverse tussen Amerikanen en Engelsen, die ver uitging boven de bekende meningsverschillen op strategisch gebied of de persoonlijke rivaliteiten en wrijvingen, is het meest opzienbarende nieuwtje in Kolkos boek. Maar van belang is ook, dat hij, lijnrecht in strijd met Fleming, Alperovitz en Horowitz, ook in Roosevelt al de exponent van deze politiek van economische expansie tekent en niet de man van een zuivere coöperatiegedachte. Opmerkelijk is verder, dat de auteur in de Sovjet-Unie een conservatieve mogendheid ziet, die uitsluitend een nationaalrussische politiek voerde en daarom een samenwerking met het Westen, op basis van een verdeling in invloedssferen, begeerde. Stalin hielp het Westen de sterke communistische bewegingen in West-Europa in toom te houden en stelde zich dus in feite ook op aan de kant van de reactie tegen de echte revolutie. Maar Amerika met zijn mondiale kapitalistische ambities dreef de Sovjet-Unie in de armen van de revolutionaire bewegingen, niet in staat het verschil te zien $^{25}$. Zo werden de v.s. de machtige aanvoerder van de contrarevolutie, de geduchte tegenstander van sociale hervormingen en vooruitgang in Azië en elders.

Penetranter nog dan bij Horowitz vormt de huidige problematiek bij Kolko het kader, waarin hij denkt en zijn vragen stelt.

Wat de hier genoemde auteurs gemeen hebben, bij alle verschil, springt in het oog: de koude oorlog wordt niet als een onvermijdelijk verschijnsel, de politiek van het Westen niet als dwangmatig opgevat. In tegendeel, zij is in hoge mate verant-

24. GABRIEL KOLKO, The Politics of War. Allied Diplomacy and the World Crisis of 1943-45 (London, 1969).

25. Vgl. KOLKO, a.w., 445 . 
woordelijk voor de breuk van de oorlogsalliantie. Of dat nu aan een diep gewortelde anti-communistische traditie ligt, zoals bij Fleming, aan de expansieve Amerikaanse economie en de politiek van de open deur, zoals bij Williams en Kolko, aan een soort chantagediplomatie, gebaseerd op het bezit van de A-bom, zoals bij Alperowitz, of aan de contra-revolutionaire impuls van de Amerikaanse politiek, zoals bij Horowitz ... de Sovjet-Unie verschijnt als respondent, die reageerde op een Amerikaanse uitdaging. De kritiek op het Amerikaanse beleid en denken kan tussen twee haakjes ook als een staaltje van Amerikaans zelfbewustzijn worden gezien, omdat zij impliceert, dat het aan Amerika was en nog is, om boven alle anderen de koers van de geschiedenis te bepalen. Rusland wordt dus gespaard. De marxistische ideologie, die in de traditionalistische literatuur óf centraal staat óf althans toch één van de factoren is, die de snelle verslechtering van de OostWest verhouding verklaren, speelt hoegenaamd geen rol. Wel daarentegen de Amerikaanse concepties en tradities, die juist weer in de oudere historiografie niet nader worden bekeken en geanalyseerd, of het moest zijn vanuit het tegenovergestelde gezichtspunt: als té idealistisch, té naïef in vergelijking met de diabolische ideologie van de tegenstander.

Wat leert nu een nadere confrontatie van de belangrijkste nieuwe opvattingen met de oudere voorstelling, zoals zij in tal van historische studies te vinden is? Ik noem hier slechts de forse werken van Hardy Mac Neill, A. Fontaine ${ }^{26}$ en het veel recentere boek van A. Ulam ${ }^{27}$.

Het is goed allereerst daarbij te onderstrepen, dat evenals bij de revisionisten, ook bij de traditionalisten zeer grote onderlinge verschillen opvallen in vraagstelling, waardering en klemtoon. Bovendien blijken beide richtingen het dan weer eens te zijn bij bepaalde detailkwesties. Vaak ook lopen de redeneringen parallel en alleen bij de uiteindelijke conclusie komen de voortekens anders te staan.

Een van de centrale discussiepunten is stellig het belang van de dood van Roosevelt, dat ten nauwste samenhangt met de beoordeling van zijn hele figuur. De president is meer dan een van de anderen een soort graadmeter voor standplaats en karakter van de betreffende auteur. Fleming, Alperovitz en Horowitz ${ }^{28}$ wijzen met de grootst denkbare klem op de verharding van de Amerikaanse houding na zijn dood, waardoor de Russen zich bedreigd moesten voelen en de coöperatie van de president onmogelijk werd. Die verharding hadden ook anderen natuurlijk opgemerkt maar dan als reactie op het Russische optreden. De term 'verharding', die een negatieve lading heeft, werd dan ook niet gebruikt en liever sprak men van 'realisme'. Het belang, dat de revisionisten aan Roosevelts dood toekennen, vloeit

26. A. FONTAINE, Histoire de la guerre froide, 2 dln. (Paris, 1966.)

27. A. ULAM, Expansion and Coexistence, the History of Soviet Foreign Policy from 1917-1967 (London, 1968).

28. FLEMING, 265; ALPEROVITZ, 19; HOROWITZ, From Jalta to Vietnam, 31. 
voort uit de veronderstelling, dat zijn coöperatiepolitiek terdege kansen had gehad. Wat in de jaren vijftig illusionisme leek, krijgt bij de huidige toenadering tussen de twee reuzen een ander gezicht. Roosevelts weg verschijnt niet meer als een pad, dat in een hinderlaag uitmondt, maar als het enige, dat nog een toekomst heeft. Die verharding wordt toegeschreven aan de invloed van figuren als Harriman, Leahy, Forrestal, majoor Deane, die bij de onervaren Truman open oren vonden ${ }^{29}$. Ook het verschil tussen Roosevelt en de nieuwe president, een conservatieve binnenlander uit Missouri, wordt onderstreept. Trumans uitlating uit 1941, dat Duitsland en Rusland elkaar het beste wederzijds konden afmatten, groeit uit tot symbolische betekenis ${ }^{30}$. Niet dat de Trumanadministratie beschuldigd wordt bewust op een breuk te hebben aangestuurd. Ook de revisionisten laten wel doorschemeren, dat het Amerikaanse beleid in de jaren 1945 en 1946 niet vrij was van schommelingen en inconsequenties. Maar van een echte bereidheid tot samenwerking, van een poging begrip op te brengen voor de Sovjet-Unie was geen sprake meer, in tegenstelling tot Roosevelt, stellen de drie hier genoemden met nadruk ${ }^{31}$.

Alvorens de importantie van het wegvallen van Roosevelt zelf nader te bekijken, moeten we erkennen, dat de omgangsstijl met de Russen bij Truman al dadelijk sterk verandert. Er is een onmiskenbare onwil om met de Sovjet-Unie samen te werken op andere dan Amerikaanse voorwaarden. Het materiaal, dat zowel de oudere historici als de revisionisten aandragen, laat geen andere conclusie toe. Een onwil, die gebaseerd was op het militaire superioriteitsgevoel. Maar ook op het morele superioriteitsgevoel, want Washington achtte het zijn recht en zijn plicht om zich als zedenmeester op te werpen tegenover de Russen. Plastisch uitte zich dat gevoel in Trumans ongeduldige uitroep, dat als de Russen niet wilden samenwerken '. .. they could go to hell ${ }^{32}$. Plastischer nog in die beruchte eerste ontmoeting tussen Truman en Molotof in het Witte Huis op 23 april. De president las de Rus hier de les over wat hij noemde het Russische verzuim om de afspraken van Jalta, speciaal in zake Polen, na te komen. En hij deed dat, om de journalist Drew Pearson te citeren, in het jargon van een muilezeldrijver uit Missouri ${ }^{33}$. 'Zo heeft nog nooit in mijn hele leven iemand met mij gesproken' zei Molotof, waarop Truman: 'Carry out your agreements and you won't get talked to like that. ${ }^{34}$

29. FLEMING, 266/267; ALPEROVITZ, 21; HOROWITZ, 32.

30. FLEMING, 135, geciteerd uit The New York Times, July 24, 1941; HOROWITZ, 59.

31. Vooral FLEMING, 218 en HOROWITZ, 25, 31.

32. JAMES v. FORRESTAL, Diaries, 148 Ook HOROWITZ, 35.

33. FLEMING, I, 268.

34. TRUMAN, Memoirs, I, 82. Voor de rechtlijnig denkende Truman is juist dat morele superioriteitsgevoel kenmerkend. In September '45 merkt hij bijv. in een memorandum op 'I'm tired of babying the Soviets', vgl. TRUMAN, Memoirs, n, 552. Maar de president stond bepaald niet alleen. Zo schreef Harriman, die men moeilijk van onkunde t.a.v. Sovjet-Rusland kon beschuldigen, in 1944 aan Hull 'We have a long and perhaps difficult road, while the Soviets learn how to behave in the civilized world community. ..' Vgl. KOLKO, a.w., 51. 
$\mathrm{Nu}$ behoeft men aan zo'n gesprek misschien niet die waarde toe te kennen, die Fleming en Horowitz er kennelijk aan hechten. Een man als Molotof kon om te beginnen wel wat incasseren zonder van zijn apropos af te raken. De toon, die Stalin bij gelegenheid, ook tegenover buitenlanders, kon aanslaan, was eveneens berekend op de huid van een muilezel. Aan de andere kant viel deze ontmoeting op een belangrijk moment. De conferentie van San Fransisco zou net beginnen. Bovendien ging het over zeer cruciële zaken, zoals Polen. En dan, het was de eerste indruk, die de tweede man van de Sovjet-Unie kreeg van de nieuwe eerste man van de Verenigde Staten. Het was stellig één van vele aanwijzingen, dat er een andere wind uit Washington begon te waaien: coöperatie op Amerikaanse voorwaarden. Maar - en hier ligt het cruciële punt, ook voor de historische beoordeling - in hoeverre was Truman, in hoeverre waren zijn adviseurs zich daarvan bewust? Truman zelf en ook anderen meenden slechts de tijdens Roosevelt gemaakte afspraken uit te voeren, zoals zij die afspraken interpreteerden ${ }^{35}$. Een man als Leahy echter, die in Jalta was geweest en die overigens ook een hardere koers aanbeval, zag al dat Jalta voor velerlei uitleg vatbaar was ${ }^{36}$. Ik kom daar op terug. In elk geval hadden Truman en zijn adviseurs niet de hoop op coöperatie als zodanig opgegeven. Zij meenden alleen, dat men andere middelen moest gebruiken om de Sovjet-Unie mee te krijgen; minder suikerklontjes, meer zweepgeknal. Maar Washington was nog lang niet consequent hierbij en zo liepen pogingen om de oorlogsalliantie nog in harmonie te prolongeren, zoals de zending van Hopkins naar Stalin in $\mathrm{mei}^{37}$, samen met pogingen om de samenwerking af te dwingen, die in Moskou op chantage moesten lijken. Dat geldt vooral voor de abrupte stopzetting van de leen- en pachtwetleveringen in april en voor de grotere terughoudendheid ten opzichte van leningen voor de Russische wederopbouw ${ }^{38}$. Geldt

35. Truman verklaarde aan Molotof, dat er maar één interpretatie van Jalta bestond, '. . .All we are asking was that the Soviet Gouvernement carry out the crimean decision.' Vgl. TRUMAN, Memoirs, I, 82. Ook ALPEROVITZ, 33.

36. Leahy merkte tegen Roosevelt op, dat de afspraken van Jalta zo elastisch waren, dat de Soviets '.. xan stretch it all the way from Jalta to Washington, without ever breaking it,' waarop Roosevelt verzuchtte 'I know Bill, I know.' LEAHY, 315.

37. Vgl. FLEMING, I, 269 en M. F. HERZ, Beginnings of the Cold War (London/Bloomington, 1966) 19. Hopkins was door Truman gezonden om direct aan Stalin te appelleren. Volgens ALPEROVITZ, 80/81, in verband met het besluit een 'show-down' nog uit te stellen tot de A-bom er was; een verklaring die wel erg monocausaal is, gezien de evidente schommelingen en ambivalenties van de Amerikaanse politiek juist in deze tijd. Want een motief voor de Hopkins-missie was ook, dat Truman zelf een ontmoeting met Stalin nog wilde uitstellen. In de grieven, die Stalin opsomde, nam de abrupte stopzetting van lend-lease een belangrijke plaats in. Stalin gaf te kennen, dat men hierin een poging had gevoeld de Russen onder druk te zetten, hetgeen Hopkins ontkende, misschien te goeder trouw. Het is evenwel duidelijk, dat Stalin met zijn vermoeden vrij dicht bij de waarheid zat.

38. Zo had Harriman al in januari ' 45 aan Stettinius geschreven over: 'my very strong and earnest opinion that the question of the credit should be tied into our overall diplomatic relations with the Soviet Union and at the appropriate time the Russians should be given to 
het ook voor de A-bom? Ulam heeft Alperovitz in dit verband verweten, dat hij zijn stelling nergens waar maakt ${ }^{39}$. Bij geen enkel conflict immers hebben de Amerikanen naar hun bom verwezen of hun heil gezocht bij een ultimatieve diplomatie. Hoe kan Alperovitz dan van atomaire chantage spreken? Maar zo eenvoudig ligt het niet. Ulam heeft stellig gelijk, wanneer hij constateert, dat van een ultimatieve diplomatie geen sprake was, wat de A-bom betreft. Maar Alperovitz heeft ook gelijk, wanneer hij laat zien, dat de show-down-gedachte - op basis van het atoommonopolie - vanaf april in de achterhoofden van de Amerikaanse diplomatie heeft meegespeeld en haar beslissingen heeft meebeïnvloed. Zo pleitte minister van oorlog Stimson, die algemeen als een van de bekwaamste figuren ook nog uit de Roosevelt-era wordt beschreven, in april voor uitstel van een showdown, totdat Amerika de bom had beproefd ${ }^{40}$. Van een atomaire diplomatie te spreken, zoals Alperovitz doet, is een onhoudbare simplificatie. Maar dat Washington door het bezit van de bom het gevoel van militaire onaantastbaarheid kreeg en vanuit dat gevoel forser optrad dan het anders zou hebben gedaan ligt voor de hand. Dat bleek in Potsdam. Een voorbeeld vormt ook Trumans verklaring in augustus nog onder de indruk van Hiroshima. De president zei daarin, op Bulgarije en Roemenië doelend: 'These nations are not to be spheres of influence of any one power $^{\prime 11}$, een overduidelijke hint, dat de v.s. de Russische politiek in Oost-Europa niet namen.

Maar natuurlijk moet ook de vraag gesteld worden, en hier zwijgt Alperovitz, of men van de v.s., of men van enige mogendheid iets anders kan en mag verwachten, dan dat zij politiek bedrijft op basis van haar machtsmiddelen. Waar Washington zich op verkeek, dat was het effect van de 'indirecte' of 'discrete' show-down. Men speculeerde er op, dat de Russen zouden inbinden omdat Amerika de atomaire stok achter de deur had. Maar de stok bleef achter de deur en de Sovjet-Unie zag daarom geen aanleiding om toe te geven in zaken, die voor haar prioriteiten vormden.

Zonder hiermee 'de schuld' van de verdere verwijdering en dus van de koude oorlog Truman c.s. in de schoenen te schuiven, zoals Horowitz, Alperovitz en ook Fleming doen, kunnen we erkennen, dat zij ons de ogen geopend hebben voor het feit, dat Washington een andere aanpak ontwikkelde om een pax americana te

understand that our willingness to cooperate wholeheartedly with them in their vast reconstruction problems will depend upon their behaviour in international matters. I feel, too, that the eventual Lend-Lease settlement should also be borne in mind in this connection.' KOLKO, 339.

39. A. ULAM 'Re-reading the Cold War', Interplay, maart 1969r

40. ALPEROVITZ, 55. A. zegt ook duidelijk, p. 58, dat Stimson de bom niet als dreiging wilde gebruiken, maar dat hij het bezit van het geheim als Amerikaanse troefkaart wilde uitspelen in het diplomatieke touwtrekken met de Sovjet-Unie.

41. ALPEROVITZ, 202. 
verwezenlijken: bereid tot verdere samenwerking met de Sovjet-Unie, maar niet van zins om over een andere interpretatie van de vredesorde te discussiëren en bereid ook in toenemende mate, om maatregelen te nemen tegen de Russen, die dat concept dwarsboomden.

Daarmee raken we echter de kernvraag van de hele problematiek. Omdat een pax americana voor de v.s., maar ook voor heel het Westen in beginsel de 'natuurlijke' en 'vanzelfsprekende' ordening was, gebaseerd op de democratische vrijheden en de Westelijke traditie en maatschappijopvatting, moest de Sovjet-Unie als spelbreker verschijnen en kregen die maatregelen tegen de spelbreker een defensief en moreel gerechtvaardigd karakter ${ }^{42}$. Vandaar dat de traditionele geschiedschrijving wel diezelfde verandering van stijl en aanpak na de dood van Roosevelt kon signaleren, zonder daar iets anders in te zien, dan de normale reactie van een land, dat zich tegenover een onscrupuleuze agressieve tegenspeler ziet geplaatst. Daarbij openbaart zich vanzelf die onontwarbare verstrengeling van ideologie en machtspolitiek. Want het nemen van maatregelen in de vorm van economische pressie, stichting van militaire bases, oprichting van bondgenootschappen en last but not least door beïnvloeding van de publieke opinie ... is een vorm van machtspolitiek in de ogen van degene, tegen wie ze gericht zijn. In de beïnvloeding van de publieke opinie ziet hij propaganda, waar de ander van informatie spreekt. De schuldvraag blijkt hier inadequaat, want van schuld kan alleen gesproken worden, waar een gemeenschappelijk normenstelsel bestaat en een gemeenschappelijk vocabularium. De Westerse stilzwijgende veronderstelling was, dat er zo'n uitgangspunt bestond, gegrondvest op de gezamenlijke verklaringen van de Grote Drie tijdens de oorlog.

Dat brengt ons tenslotte onvermijdelijk terug naar die afspraken en naar de oorlogsalliantie zelf. En daarmee zijn we tevens opnieuw terug bij de vraag naar de betekenis van Roosevelts dood, die we alszodanig nog open gelaten hebben. Door echter bij de ambtsaanvaarding van Truman te beginnen, suggereert men al heel gemakkelijk, dat hier de drempel ligt. Dit lijkt mij een uitgesproken bezwaar tegen zowel Alperovitz als Horowitz. En Fleming begint weliswaar zijn relaas in 1917 en staat op dit punt dus ijzersterk, een duidelijke caesuur ziet ook hij na de dood van Roosevelt. Hetgeen dan ook een betrekkelijk geringe diepgang verraadt.

42. FLEMING, 278 heeft stellig gelijk, wanneer hij opmerkt, dat de Amerikanen twee maten hanteerden. Tal van vooraanstaande politici drongen telkens weer op een revisie en democratisering van Oost-Europa aan en Herbert Hoover schreef bijv. 'Americans for all time will sorrow for the fate of Finland, of Estonia, of Latvia, of Lithunia, the partition of Poland, and other states, that will be partly or wholly submerged by this war.' geciteerd bij FLEMING, ibid. Aan de andere kant stonden zij op hun recht de zaken in hun eigen belangensfeer volkomen souverein en ook buiten bemoeienis van de UNO om te regelen. Zo beval Senator Vandenberg aan 'to accept .. . exclusive responsibility for any armed forces required to maintain peace and security in the Western Hemisphere. I doubt wether we shall ever want any armed forces to enter this area.' 
We kunnen niet volstaan met de nieuwe stijl te signaleren. We moeten ook vragen, waaruit die voortkwam. Het is de verdienste van MacNeill, Feis en Ulam, maar ook van Kolko, dat zij de hele oorlogsalliantie doorlichten. Wat leert ons die analyse?

Allereerst is het nodig om vast te houden, dat het oude wantrouwen tussen Engeland en de Sovjet-Unie altijd onder de grond bleef doorrommelen. Er was een Hitler voor nodig om Churchill en Stalin beiden naast elkaar op één bank te krijgen, breed grijnzend nog wel; maar dat was dan ook duidelijk een bewijs, dat zij deze wereldhistorische grap apprecieerden. Wanneer we vervolgens aan Britse kant, ook en vooral bij Churchill zelf, een crescendo van bewondering, kameraadschappelijkheid en momenteel optimisme tegenkomen, dan moet dat gelezen worden tegen de achtergrond van het oude antagonisme. De Britten dachten daarbij altijd in de traditionele kategorieën van machtsevenwicht. Het Engelse streven was er op gericht om andere gegadigden te vinden voor de last, die voor de eigen schouders te zwaar begon te worden. Vandaar de hardnekkige worsteling van Churchill en Eden om Frankrijk weer op te vijzelen tot Grote Mogendheid ${ }^{43}$. Vandaar hun angst voor een totaal ontredderd Duitsland. Vandaar hun pogingen zoiets als een West-Europees blok te creëren ${ }^{44}$ en hun streven om invloedsferen vast te leggen en met Moskou te komen tot een regeling over Polen en de Balkanlanden. Maar die balance-of-power-politiek stuitte af op het resolute Amerikaanse veto. De gedachte van een mondiaal veiligheidsstelsel in de geest van Wilson vond vooral in Cordell Hull en het State Department overtuigde aanhangers, die principieel en vasthoudend elke blokvorming trachtten te beletten. Zij slaagden er doorgaans in om Roosevelt voor hun koers te winnen. Dat betekende, dat Churchill en de Engelsen, wilden zij niet de nauwe relatie tot de grote broer, die voor hun van vitaal belang was, op het spel zetten, mee moesten gaan met de Amerikaanse universalistische denkbeelden. Weliswaar met één belangrijke restrictie: het Britse Gemenebest mocht niet het slachtoffer worden van de Amerikaanse hervormingsijver ${ }^{45}$. Want kernstuk van Churchills politiek vormde de wil om het Imperium zo ongeschonden mogelijk uit de wereldbrand te redden en daarnaast het Europese evenwicht te herstellen, dat Duitse bruutheid en stompzinnigheid had verstoord. Wanneer hij uiterlijk daarbij altijd de grote opponent van Sovjet-

43. Stalin voelde er niet voor om de Fransen een bezettingszone te geven, noch een zetel in de geallieerde contröleraad in Berlijn. De Britten kregen dit tenslotte echter gedaan, waarbij hun voornaamste motief verlichting van hun zware bezettingstaak was. De onzekerheid over de Amerikaanse demobilisatieplannen speelde stellig een grote rol hierbij.

44. Vgl. KOLKO, a.w., 72.

45. Zo werden in het Atlantisch Handvest, dé eerste algemene beginselverklaring, al dadelijk restricties ingevoegd, die de aparte status van het Gemenebest onderstreepten in het kader van het op dekolonisatie gerichte beleid van de Amerikanen. Bekend is ook Churchills uitspraak, dat hij niet Prime-Minister was geworden om de liquidatie van het Britse imperium te voltrekken. Op dit gebied kwam het tot de scherpste controverses tussen hem en Roosevelt. 
Rusland leek, dan was dat voor een groot deel juist het gevolg van zijn streven om mét Moskou tot een aanvaardbare regeling te komen ${ }^{46}$. In zijn denken en stijl stond hij in wezen dan ook veel dichter bij Stalin dan Roosevelt. Want ook Stalin en Molotof dachten in kategorieën van machtsevenwicht en waren op een verdeling van invloedsferen uit. Primair voor hen stond de nationale veiligheid van de Sovjet-Unie. Daarom wensten zij een gordel van bevriende regeringen en een uitbouw van hun staat, die elke toekomstige agressie onmogelijk zou maken en het snelle economische herstel zou bevorderen. Zoals allen, die handelen, dachten zij in prioriteiten. De Westerse mogendheden waren een machtsfactor. De wereldrevolutie was toekomstmuziek. Stalins hele loopbaan wijst erop, dat hij uiterst sceptisch stond tegenover buitenlandse communistische partijen en met zeer gemengde gevoelens het succes van autochtone communistenleiders aanschouwde. Hij hanteerde het internationale communisme en de leninistische leer als instrument in dienst van zijn pragmatische politiek.

Maar met de bereidheid van London en Moskou om in principe Europa in invloedsferen te verdelen was het natuurlijk niet gedaan, nog afgezien van het Amerikaanse veto. De wisselende oorlogssituatie betekende een constante verleiding om nog even met regelingen te wachten, wanneer de eigen positie er beter op leek te worden. Hoe somberder de toekomstperspectieven, des te meer behoefte was er aan een afspraak. Zo toonde Moskou in de meest benarde jaren 1941/42 grote belangstelling voor een grensregeling met Polen ${ }^{47}$. Stalin liet zelfs in de winter 1941, toen het Duitse mes, of liever de Duitse kanonnen hem belaagden, doorschemeren, dat hij het Polen van 1938 met enkele kleine grenscorrecties 'zo tchou tchou' wel wilde accepteren. Een kerstsprookjesachtig aanbod in het licht van de latere ontwikkeling! Maar Sikorski, de Poolse premier, ging er niet op in. Niemand wist nog of de Sovjet-Unie het zou houden en of Stalin niet over een paar weken blij zou zijn met een rudiment van zijn oude macht. Het moment kwam nooit meer terug ${ }^{48}$. De grens van 1941 (vóór de Duitse aanval uiteraard), dat was voortaan de Russische eis en in 1943 en 1944 is het Churchill, die dat dan tenminste

46. Ondanks de enorme literatuur ontbreekt nog een afgeronde analyse van Churchills denkbeelden en politiek, die minder eenvoudig te peilen zijn, dan gewoonlijk wordt aangenomen.

47. De Sovjet-Unie trachtte al spoedig na het verbond met Engeland een Britse erkenning van de grenzen van 1941, dus vóór Hitlers aanval, los te krijgen, hetgeen op erkenning van het Ribbentrop-Molotofpact neerkwam, althans wat het Russische aandeel betreft. De Engelsen verklaarden bij monde van Eden, dat zij de grenzen van 1939 (dus het Polen uit het Interbellum) niet meer erkenden, zonder zich al vast te leggen op een nieuwe regeling. Vgl. naast MAC NEILL, a.w., FEIS, a.w. en FLEMING, a.w. voor de Poolse kwestie speciaal EDWARD I. ROZEK, Allied Wartime Diplomacy. A Pattern in Poland (New York, 1958). Verder IWAN MAISKY, Memoirs ofa Soviet Ambassador. The War 1939-43 (London, 1967) en R. UMIATOWSKI, Poland, Russia and Great Britain (London, 1946).

48. Vgl. ROZEK, a.w. en W. W. KULSKI, 'The lost opportunity for Russian-Polish Friendship', Foreign Affairs, 25 juli 1947. 


\section{H. W. VON DER DUNK}

graag zwart op wit wil hebben, wa'arbij de Engelsen trouwens liever van de Curzonlijn spraken als basis voor de toekomstige regeling ${ }^{49}$. Dat het in het geval Polen niet tot een Brits-Russische regeling kwam, lag behalve aan de Amerikaanse houding ${ }^{50}$ natuurlijk, en in eerste instantie, aan de vierkante weigering van de Poolse regering in London, om ook maar over iets anders te denken dan het Polen van 1938, waarbij men overigens niets tegen uitbreiding naar het Westen had. Bij de andere Oost-Europese landen lag dat anders, ook al omdat zij óf aan Duitse kant hadden gestaan óf passief waren gebleven. Zo konden Stalin en Churchill in oktober 1944 die befaamde regeling treffen, waarbij percentages van invloed voor ieder in de diverse Balkan-landen werden opgesteld ${ }^{51}$. Deze overeenkomst was een volkomen schertsregeling en tevens van zeer groot belang. Een schertsregeling, want niemand kon zeggen, wat men zich in de practijk moest voorstellen, wanneer zoals bijv. in Bulgarije de Russen $75 \%$ en het Westen $25 \%$ invloed zou mogen uitoefenen. En niemand kon precies zeggen of dit als provisorium was bedoeld of als aanwijzing voor de toekomst. Maar tevens een afspraak van zeer groot belang, omdat hier, hoe miserabel ook, het beginsel van een balance-of-power-politiek werd toegepast, die de Amerikaanse politiek doorkruiste. En Churchill zelf heeft Stalin geattesteerd, dat hij zich stipt aan die afspraak hield, toen de Engelsen in december 1944 met geweld in Griekenland ingrepen, om de monarchie te herstellen ${ }^{52}$. Stalin verroerde geen vin.

49. Churchill en Eden waren nooit zo afkerig van erkenning van de Curzon-lijn. Die grens ging tenslotte terug op een Engels voorstel uit 1920. Volgens etnografische kriteria, die destijds de doorslag hadden gegeven bij het voorstel van Lord Curzon, was het recht van Polen op de gebieden oostelijk van die lijn zeer kwestieus, omdat hier slechts een Poolse minderheid leefde. Het grote Polen van 1938 was niet het resultaat van een internationale regeling, maar van de Poolse overwinning op de Soyjct-Unie in 1921. Primair voor Churchill was, dat Polen een Westers regeringsstelsel kreeg. Daarvoor meende hij, dat territoriale concessies aan de Sovjetunie te rechtvaardigen waren en hij vreesde al gauw, dat intransigentie op het punt van de grenskwestie de kansen op zo'n regeringsstelsel zou verminderen; terecht, zoals de afloop zou leren.

50. Voor de nogal felle Amerikaanse reacties op alle Brits-Russische regelingen, die vooruitliepen op de latere vrede, met name van Hull en Summer Wells vgl. Foreign Relations of the U.S., 1942, Europe, III, 517/18, 520, 542, 510 en 525.

51. Vgl. CHURCHILL, a.w., VI, 197.

52. CHURCHILL, a.w. VI, 255. De destijds en ook nu nog wel in het Westen gangbare opvatting, dat Griekenland de keuze had tussen Communisme en constitutionele monarchie is onhoudbaar. De ELAS/EAM, de Griekse verzetsbeweging, bestond uit een doorsnee van alle linkse groeperingen, ook republikeinen en socialisten. Zij werd door de brede lagen van de bevolking gedragen. De Communisten speelden wel een centrale rol, maar waren evenmin Moskou-horig als Tito. Het werkelijke alternatiefin 1944 voor Griekenland luidde veeleer: republiek van sterk sociaal-reformistische signatuur - hetgeen uiteraard een grote kans tot een ontwikkeling in Joegoslavische zin inhield - of monarchie, gedragen door het leger en de oude leidende kringen, die sterk met de Duitsers hadden gecollaboreerd. Vgl. STEPHEN XYDIS, 'The Secret Anglo-Soviet agreement on the Balkans', Journal of Centr. European Affairs, XV; FR. SMOTHERS e.a., Report on the Greeks (New York, 1948) en MAC NEILL, 'The outbreak of Fighting in Athens', The American Slavic and East European Review, VII, 7. 
Wat in de practijk gebeurde werd echter in theorie op losse schroeven gezet door de beginselverklaringen van de Grote Drie, die een universalistische ordening in Amerikaanse geest suggereerden. Dat gold voor het Atlantisch Handvest, maar ook voor de andere gemeenschappelijke communiqué's. Deze beginselverklaringen verraden bovenal de geest van Roosevelt. En dat brengt ons bij de Amerikaanse toekomstconcepties en bij de hardnekkige strijd van Hull en het State Department tegen de balance-of-power-politiek.

Men pleegt in de Amerikaanse geschiedenis een isolationistische stroming te confronteren met een universalistische en ziet deze tegenstelling als een rode draad door de buitenlandse politiek geweven. Zoals met vele begrippen betreft het ook hier een wat geconstrueerde polariteit. Isolationisme en universalisme kunnen dikwijls uit dezelfde grondhouding voortkomen. Amerika immers kon slechts volledig zich zelf zijn en zich onbelemmerd aan eigen zaken wijden, wanneer de wereld vrij en democratisch, dat wil zeggen: naar Amerikaans beeld herschapen was. Evenals eertijds in de Volkenbond konden de V.S. nu in de UNO het instrument begroeten om dat te volbrengen en hen zo te ontheffen van de onbegeerde taak om als superpolitieagent zelf overal recht en orde te handhaven. De UNO was geconcipieerd als verlengstuk van de Amerikaanse politiek en het zou wat naïef zijn om de Amerikanen daar een verwijt van te maken. Nog nooit is een mogendheid, die de kans krijgt tot hervormingen en die de macht daartoe bezit over haar eigen schaduw gesprongen. De moeilijkheid, die door de na-oorlogse ontwikkeling en met name door de opkomst van de Derde Wereld onthuld zou worden is, dat er niet zoiets als een 'natuurlijke' ordening bestaat, omdat elke conceptie en elk ideaal uitdrukking zijn van een specifieke historische ontwikkeling en standplaats. Het is ongetwijfeld een belangrijke bijdrage van Williams en Kolko, dat zij gewezen hebben op het feit, dat zo'n volgens Amerikaanse opvatting, natuurlijke, wereldordening een pax americana moest betekenen en tot de economische hegemonie van de V.S. zou voeren, om de simpele reden, dat vrijheid en gelijke kansen voor alle volkeren automatisch in het voordeel van de sterkste uitvallen. Dat is een oud vers. Elke blokvorming was daarom voor Hull uit den boze, die daarbij ongetwijfeld ook de economische belangen van de V.S. voor ogen had. En Hull en het State Department hielden zich speciaal met de UNO bezig, ook omdat Roosevelt hen dikwijls niet bij allerlei actuele beslissingen betrok ${ }^{53}$. Dat laatste hangt weer samen met het Amerikaanse regeringssysteem en bovendien met de persoonlijke stijl van Roosevelt. Het gaat namelijk niet aan, om eenvoudig van één Amerikaanse politiek te spreken, die universalistisch was en elke pragmatische machtsverdeling alsmaar verhinderde. Want ook in Washington begreep men natuurlijk zeer goed, dat een nieuwe ordening alleen door een sterk Amerika kon worden verwezenlijkt.

53. Vgl. MAC NEILL, America, Britain and Russia, 26; KOLKO, a.w., 242. 
En om sterk te staan moesten de V.S. al bij voorbaat machtspolitiek bedrijven. Hierbij liepen de opvattingen van de verschillende instanties nogal uiteen, zowel wat het accent, als wat de methode betreft. De enige coördinator van al die richtingen was de president. Maar de kracht van Roosevelt school bepaald niet in het nemen van duidelijke beslissingen en in het uitzetten van een vaste lijn. Het geheim van zijn staatsmanschap bestond uiteindelijk in zijn zeldzaam vermogen een sfeer van optimisme te verspreiden, iedereen te bezielen en vertrouwen in de goede afloop te schenken. Conflicten schoof hij daarom op de lange baan, beslissingen stelde hij graag uit, in de hoop dat de tijd de mensen wijzer zou maken. Vaak niet ten onrechte. Maar diezelfde eigenschappen, die hem op het Amerikaanse forum tot een politieke persoonlijkheid zonder evenknie stempelden: het vermogen tegenstellingen te bagatelliseren en allen in een roes van eensgezinde dadendrang en sportiviteit om zich heen te scharen, diezelfde eigenschappen, die hem ook voor de publieke opinie in heel de wereld tot een bron van hoop en vertrouwen maakten, zaten hem tegen waar hij zelf partij was, waar hij geen verkiezingsstrijd naar een feestelijk einde kon brengen, geen New Deal met vaart en visie voort kon stuwen. Men heeft sterk het gevoel, dat Roosevelt in zijn buitenlands beleid altijd, soms onderbewust, de president van die New Deal bleef; dat hij de technieken, die daar succesvol waren geweest en die hem zo lagen ook tegenover zijn buitenlandse partners aanwendt, in de hoop op hetzelfde resultaat. Zijn toekomstconceptie was eveneens niet doctrinair, in de geest van Wilsons en Hulls universalisme, maar een soort mondiale New Deal, waarbij het accent minder op regelingen en principes, dan op de nieuwe geest van samenwerking en op het geniale improviseren lag.

In de practijk betekende dat echter, dat Roosevelt heen en weer schommelde tussen de verschillende politieke richtingen in Washington. Zo was zijn universalisme allerminst zo consequent als Hull het wel gewenst zou hebben. Aanvankelijk en ook later nog herhaaldelijk dacht Roosevelt aan een condominium van de grote mogendheden in of naast de $\mathrm{UNO}^{54}$. En zo liet hij ook oogluikend de verdeling in invloedsferen tussen Churchill en Stalin toe, om er zich later, onder pressie van Huil, weer nadrukkelijk van te distantiëren. Resumerend moeten we dus constateren, dat er de tegenstelling was tussen de Engels-Russische politiek aan de ene en de Amerikaanse aan de andere kant, maar daarnaast nog de interne Amerikaanse tegenstelling tussen een doctrinair universalisme van het State Department, ten nauwste gekoppeld aan het economische liberalisme; een wat vaag improvisatorisch universalisme, gebaseerd op de coöperatie van de groten bij Roosevelt, én nog een nationaal-Amerikaanse richting, die primair de belangen van de V.S.

54. KOLKO, a.w., 267. Roosevelt zag in de Grote Mogendheden staten met 'exceptional responsibilities' en hij realiseerde zich terdege, dat de UNO alleen kon functioneren bij coöperatie van de groten. Vgl. ook The Conferences at Cairo and Teheran, Foreign Relations 1943, 530. 
veilig wilde stellen en die ook bij allerlei gelegenheden via Congres of militairen zijn sporen op het beleid wist te drukken ${ }^{55}$.

Waren dus de algemene beginselverklaringen hoogst misleidend, zij waren psychologisch een noodzaak, niet enkel voor de Amerikaanse natie. De mythe van een betere toekomst kon niet gemist worden bij de geweldige inspanning, die de oorlog tegen de As-mogendheden vergde. Maar voor de insiders was duidelijk, dat er nog lang geen werkelijke overeenstemming over de toekomstige orde bestond, hetgeen de verklaring is van de vele vaagheden en onduidelijkheden in die algemene verklaringen. De Sovjet-Unie ging er van uit, dat haar veiligheidsgaranties niet door die verklaringen konden worden aangetast en Churchill deed hetzelfde, wat het Gemenebest aangaat. De Westerse staatslieden lieten Stalin telkens weten, dat zij volledig achter zijn streven naar een veiligheidsgordel stonden, maar dat die beginselverklaringen nodig waren met het oog op de publieke wereldopinie. Roosevelt was ongetwijfeld realist genoeg om de discrepantie te zien, tussen wat de SovjetUnie en ook Engeland wilden en practiseerden en de toekomstverwachtingen, die hij zelf symboliseerde. In theorie kon hij daarbij drie dingen doen:

1. Hij kon een pragmatische verdeling van invloedssferen ondersteunen, waarbij Oost-Europa in feite zonder meer aan de Sovjet-Unie werd overgelaten. Daarmee zou hij echter in botsing zijn gekomen niet alleen met het State Department, maar met de hele Amerikaanse traditie, het Amerikaanse denken en dus met zijn eigen verleden.

2. Hij kon rigoreus vasthouden aan de universalistische beginselen, hetgeen echter het risico van een breuk met de Sovjet-Unie en niet minder het risico van een uit-de-hand-lopen van de Europese ontwikkeling met zich meebracht; nog afgezien van het feit, dat men zich gezamenlijk in oorlog tegen het fascisme bevond.

3. Hij kon vasthouden aan die beginselen in beginsel, maar in de practijk oogluikend een voorlopige verdeling van invloedsferen toelaten, in de hoop de deur toch open te houden en voor Oost-Europa te redden wat er nog te redden viel. En Roosevelt zou niet Roosevelt geweest zijn, de optimist, de improvisator, wanneer hij niet voor het laatste had gekozen! Hij verwachtte, dat bij de nodige soepelheid en bij constante contacten in en buiten de UNO de discrepantie allengs zou verminderen, heilig doordrongen van de superioriteit van het Amerikaans-Westerse patroon. Dit optimisme was tevens op het laatst de vluchthaven voor een man, die fysiek volledig was uitgeput ${ }^{56}$. Maar die discrepantie tussen de Amerikaanse con-

55. Tegen het einde van de oorlog steekt het oude Isolationisme de kop weer op, dat zich veelal ook weer tegen de UNO richtte in de vastbeslotenheid de nationale souvereiniteit tegen elk supranationaal orgaan te beschermen. Vgl. ERNST-OTTO CZEMPIEL, Das amerikanische Sicherheitssystem, 1945-49 (Berlin, 1966).

56. Roosevelts gezondheidstoestand tijdens Jalta heeft ook in de hele controverse rond zijn figuur uitvoerig de aandacht gekregen, waarbij zelfs de suggestie opkwam, dat hij niet goed meer wist wat hij deed. Alle getuigen van Jalta daarentegen ontkennen met stelligheid een 
ceptie en de werkelijkheid werd ook door andere Amerikaanse politici in de loop van 1944/45 geconstateerd en zij drongen aan op maatregelen tegen het Russische opdringen. Zij propageerden dus bewust een doorbreken van de universalistische koers. En na Roosevelts dood, toen de oorlog snel zijn einde naderde, werd die discrepantie in alle scherpte opgemerkt door Truman en brede kringen in Washington. De conclusie, die men trok was, dat de russen bezig waren gemeenschappelijke afspraken te verraden ${ }^{57}$. Zorgvuldige bestudering van die afspraken leidt echter eerder tot de conclusie, dat de russen zich hielden aan de afspraken, die ondubbelzinnig waren en dat zij de vele dubbelzinnige afspraken konden interpreteren als een vrijbrief om hun gang te gaan, omdat stilzwijgend tot een verdeling in invloedsferen was besloten. Alleen hadden hun partners thuis nu eenmaal dat vijgenblad van beginselen nodig.

Wat bij het Russische optreden in Oost-Europa ook nauwelijks in het Westen werd doorzien, was dat de Oost-Europese verhoudingen zo verschilden van WestEuropa. Omdat daar een sterke liberaal-democratische traditie ontbrak en een middenklasse, die er in het Westen de drager van was, helden de politieke partijen veel meer naar een rechts- of linksradikalisme over, zoals de geschiedenis van het Interbellum leert. Het keiharde Sovjet-standpunt: 'wie niet voor ons is, is tegen ons' was daarom niet zo bezijden de waarheid als het in het Westen wel eens leek. Bovendien mag niet worden vergeten, dat Hongarije, Roemenië en Bulgarije feitelijk in het kamp van de as hadden gestaan. In Polen bestond een diep-gewortelde Russenhaat. Een vrij en tevens pro-russisch Polen kwam neer op een kalf met twee koppen. Wanneer de Westerse staatslieden volmondig Stalins eis ondersteunden, dat de Sovjet-Unie door bevriende regeringen omgeven diende te worden, dan vroegen zij zich kennelijk niet voldoende af, of dit ooit haalbaar was bij vrije verkiezingen en volledige Russische onthouding. En in nog veel sterkere mate geldt dat voor de publieke opinie, die ook geen oog had voor het zeer natuurlijke russische streven naar veiligheid. Hier was men veel meer onder de indruk van de imposante opmars en de formidabele stootkracht van het Rode Leger. De enorme verwoestingen in het land zelf en de economische zwakte werd daardoor versluierd.

geestelijke achteruitgang van de president. Men behoeft echter slechts de foto's te vergelijken om te zien, dat hier een ten dode opgeschreven man zat, hoe dan ook! Dat verklaart misschien zijn haast aan de conferentietafel. Tevens bevestigen verschillende getuigen, dat hij slecht voorbereid was en daardoor ook niet voldoende greep op de materie had. Dat laatste daarentegen was een zwakte van Roosevelt, die zich niet voor het eerst deed gelden. De fysieke uitputting, ook nog van de verkiezingscampagne, heeft dat om begrijpelijke redenen versterkt. Dat hij daardoor in de essentialia andere beslissingen genomen zou hebben is echter een mythe. Bovendien stonden zijn adviseurs klaar om te waken voor eventuele vergissingen.

57. Vgl. JOHN L. SNELL, a.w. en ook G. L. ARNOLD, 'The Cold War', The Twentieth Century, maart 1953, 165 en april, 249. Dat de Sovjets de afspraken verbraken vindt men ook met zoveel woorden in het commentaar op de Jalta-beslissingen, Foreign Relations 1945. The Conferences at Malta and Jalta, 537. 
Vergelijkt men die Russische behoefte aan veiligheidsgaranties met de Franse eisen in 1919, dan kan een en ander niet worden afgedaan als een vijgenblad voor pure imperialistische bedoelingen. Bovendien, toen de Duitsers in 1918 capituleerden stonden de Fransen net aan de Maas. Toen de Duitsers in 1945 capituleerden stond het Rode Leger in Berlijn. Houdt men zich dat voor ogen, dan zijn de Russische eisen niet zo onbescheiden.

Het verwachte herstel van de status-quo-ante in Oost-Europa betekende voor de Russen herstel van over het algemeen rechtsgeoriënteerde, op de oude sociale bovenlaag steunende regeringen, die q.q. anti-communistisch waren ingesteld. Toch duurde het nog enkele jaren, tot de zomer en herfst 1947 - na afkondiging van Trumandoctrine en Marshallhulp - tot in al deze landen het communistische éénpartijenstelsel werd ingevoerd ${ }^{58}$. Deze geleidelijke ontwikkeling naar het stalinistische model toe werd in het Westen grif als bewijs van een op lange termijn berekende zeer bekwame expansiepolitiek opgevat. Dat Stalin van begin af aan echter de communistische politiestaat voor heel Oost-Europa op zijn agenda zou hebben geplaatst en dat de hele episode van coalitie- en volksfrontregeringen in de jaren 1945-47 slechts tactiek zou zijn geweest, om de wereld zand in de ogen te strooien en zijn ware bedoelingen te versluieren, is op zijn minst een onbewezen en voorlopig ook onbewijsbare hypothese. Er zijn aanwijzingen, dat Moskou op een geleidelijke ontwikkeling in socialistische richting hoopte en altijd dan ingreep, wanneer die verwachtingen niet uitkwamen ${ }^{59}$. Wat deed Engeland in Griekenland, wat deden de V.S. bij allerlei gelegenheden anders, wanneer een door hen verwachte ontwikkeling van een land in Westers-democratische richting niet uitkwam?! Toch vormde die voorstelling van een zorgvuldig berekende lange afstand-strategie van de Russische politiek één van de dogmata achter het Westerse Ruslandbeeld, zoals dat in die na-oorlogse jaren in brede kring ontstond. En met die doelbewuste

58. FLEMING, I, 433. Dat het Marshallplan kort na afkondiging van de Trumandoctrine werd gepubliceerd, moest de oprechte bedoelingen ervan in de ogen van de Sovjet-Unie wel discrediteren. De afwijzing van het Marshallplan door Moskou wordt vaak als bewijs aangevoerd van de anti-Westelijke bedoelingen. Maar het Marshallplan kan natuurlijk niet losgedacht worden van de economische implicaties, die een open breken van Oost-Europa en ergo een sterke penetratie van Amerikaans kapitaal hadden betekend en van de politieke gevolgen voor de Russische machtspositie van zo'n penetratie. Met het oog op die ontwikkeling was het hele project ook oorspronkelijk door Acheson en het State Department geconcipieerd. Marshall persoonlijk heeft vervolgens meer het algemene opbouw-element van het plan geaccentueerd en de politieke bijbedoelingen willen elimineren. Dat in het Congres velen de Russische afwijzing met een gevoel van opluchting vernamen, was nauwelijks een geheim en het is nog de vraag of dat niet ook voor de regering zelf gold, die nu niet meer bang behoefde te wezen, dat het Congres de spelbreker zou worden.

59. Dat geldt vooral voor de ontwikkeling in de industrieel geavanceerde landen, zoals de DDR en Tsjechoslowakije. In dat laatste land tekende zich bijv. eind 1947 een teruggang van de Communistische partij af, hetgeen de gebeurtenissen in februari 1948 mede helpt verklaren. FLEMING, I, 492. 
Russische expansiepolitiek, waar de Oost-Europese ontwikkeling het bewijs van scheen te leveren, werd dan de politiek van Amerika en het Westen in 't algemeen geconfronteerd als een achter-de-gebeurtenissen-aanstrompelen en als onhandige improvisatie zonder lijn en beleid. Zo leek het. Maar leek het ook zo in Russische ogen? Een parallelisme met de Russisch-communistische voorstelling van zaken is namelijk frappant. Daar werd nu juist aan de Amerikaans-Westerse politiek een doelbewuste imperialistische complot-strategie toegeschreven: de vereniging van de Westelijke bezettingszones, de oprichting van de NATO, de herbewapening van de Bondsrepubliek verschijnen in deze optiek als volstrekt consequente stappen op een uitgestippelde weg. Een bewijs opnieuw, dat de optiek niet het resultaat van gebeurtenissen is, maar dat de optiek bepaalt, hoe wij de gebeurtenissen rangschikken. Is dus allerminst bewezen - en zelfs op grond van allerlei aanwijzingen onwaarschijnlijk - dat Rusland op een systematische stalinisatie van Oost-Europa aanstuurde, het blijft begrijpelijk, dat in het Westen deze indruk ontstond. Al werd die indruk dan ook al snel en zeer bewust verder geregisseerd en gemanipuleerd. En het blijft begrijpelijk, dat een vergelijking tussen het Russische optreden in Oost-Europa en de toekomstverwachtingen voor het Westen tot de conclusie moest leiden, dat de Russen gemaakte afspraken schonden.

Ten onrechte; want wie door de verbale sluier heenprikt en de wordingsgeschiedenis van al die afspraken bestudeert, moet tot de conclusie komen, dat de Sovjets het gevoel hadden, dat zij in Oost-Europa hun gang konden gaan, zoals zij Amerikanen en Engelsen hun gang lieten gaan in Italië, Griekenland en elders ${ }^{60}$. Die beginselverklaringen waren immers bedoeld als de ideologische verpakking van deze balance-of-power-politiek, die in zo'n Westelijke democratie blijkbaar nodig waren. Het is soms komisch om te lezen, hoe Roosevelt het belang van de publieke opinie met veel gewicht onderstreept tegenover een beleefd-ongelovige Stalin, die eigenlijk niet goed begreep, waarom die publieke opinie dan niet wat beter werd geregisseerd $^{61}$. Zo moeilijk was dat toch niet! In de verontwaardiging en protesten van Westelijke kant, toen zij eind 1944 begin 1945 hun aandeel op hun manier begonnen te incasseren, konden de Sovjets daarom eveneens een verloochening zien van een gemeenschappelijk overeengekomen koers en een hypocriete poging tot hernieuwde inkapseling, nu men hen niet meer nodig had. . . naar analogie van 1919.

60. Bij de onderhandelingen met Italië na de val van Mussolini werden de Russen nauwelijks betrokken. Op dat precedent - N.B. waar het één van de beide As-mogendheden betrof! beriepen de Russen zich natuurlijk later bij hun unilaterale beslissingen in Oost-Europa. Voor Griekenland zie noot 52 .

61. Vgl. Foreign Relations. The conferences at Cairo and Teheran, 594. Van Wyshinski is de veelzeggende opmerking overgeleverd, dat het Amerikaanse volk zijn leiders moest leren gehoorzamen, SHERWOOD, Roosevelt and Hopkins, 852, 861. Ook bij alle onderhandelingen met de Engelsen trouwens is het eerste Amerikaanse argument bij meningsverschillen telkens en telkens de verwijzing naar de publieke opinie. 
Al vanaf de late herfst 1944 en zeker in het voorjaar gingen er in het Westen stemmen op, die voor de grote Russische machtsaanwas waarschuwden ${ }^{62}$. In de oudere literatuur krijgen deze stemmen dikwijls van wege hun realisme zeer hoge cijfers. Men kan echter ook de zaak omkeren en erop wijzen, dat zo'n nieuw 'realisme', dat het Kremlin uiteraard niet ontging, juist diens oude wantrouwen wekte en de spanning vergrootte. Nu mag men niet menen, dat bij een bewuste, van alle ideologische franje ontblote balance-of-power-politiek aan weerszijden alle moeilijkheden zouden zijn vermeden. Wel kan men zich theoretisch voorstellen, dat het Westen en de Sovjet-Unie, na veel touwtrekken, overeenstemming hadden bereikt over een afbakening van invloedssferen. Elk wist dan waar hij aan toe was en voor teleurstellingen en verdachtmaking op grote schaal zou veel minder aanleiding geweest zijn.

In dit verband is een andere stroming van belang in de recente Amerikaanse historiografie, die echter ook momenteel in Europa veel aanhangers vindt: het nieuwe pragmatisme: de opvatting, dat politiek uitsluitend door de machtsverhoudingen wordt bepaald en daarom los van alle ideologische desiderata en vertroebeling, nuchter op basis van de eigen inherente wetten en spelregels bedreven dient te worden. Het verwijt van de neo-pragmatici aan de V.S. luidt daarbij, dat zij, bij gebrek aan een lange historische ervaring met dit machtsspel, politiek meenden te kunnen bedrijven op basis van beginselen. Dat komt bijv. tot uiting bij Louis Halle, The Cold War as History ${ }^{63}$. Halle, zelf functionaris bij het State Department, schildert de koude oorlog af als zo'n zuiver machtsconflict, dat gedetermineerd was en door niemand gewild. Het Europese machtsvacuüm zoog de Sovjet-Unie naar binnen, zonder dat Stalin bewust op een expansie uit was. De V.S. moesten toen als tegenwicht fungeren en de oude rol van Engeland overnemen. Daar lag de kern van het conflict, dat in feite al sedert 1942 onvermijdelijk was. Halle wijst op de angst, die sedert het einde van 1944 in het State Department heerste voor het toekomstige conflict met de Sovjet-Unie. Men zag dit daar zeer goed, maar Amerika was er nog niet rijp voor, bevangen in ideologisch denken. De puur pragmatische benadering was - helaas - niet mogelijk, meent Halle. Nu blijft zijn redenatie in zoverre onbevredigend, omdat niet precies duidelijk wordt, wat er in zijn ogen bij die door hem gepropageerde pragmatische politiek gewonnen zou zijn. De koude oorlog was immers toch onvermijdelijk, omdat het een machtsconflict betrof, dat zich buiten het denken en willen van de handelende personen om, volgens autonome wetten voltrok. Men zou daarom kunnen repliceren, dat het lood om oud ijzer was in welke vermomming men dit onpersoonlijke fatum laat optreden. Kritiek op het gebrek aan pragmatisme in het Amerikaans beleid heeft

62. Speciaal Harriman, Kennan en majoor Deane moeten in dit verband worden genoemd.

Vgl. KENNAN, Memoirs, 216. Zie ook HALLE, a.w.

63. Zie vorige noot. 


\section{H. W. VON DER DUNK}

enkel zin, wanneer men niet van een onvermijdelijk machtsconflict uitgaat, maar in dat pragmatisme een kans zag om de koude oorlog te verhinderen, althans te verzachten.

Halle is op dit punt niet duidelijk, maar het gaat er hier nu om, mét hem te constateren, dat een zuiver pragmatisme in de zin van een op invloedsferen gebaseerde politiek in 1944-45 niet mogelijk was. Aan Russische kant was men wel bereid om de koek te verdelen, zoals Stalin in 1939 ook met Hitler de koek al had verdeeld. Aan Westerse kant echter werd de Britse bereidheid om een traditionele balanceof-power-politiek te voeren doorkruist en getorpedeerd door de Amerikaanse politiek van een mondiaal veiligheidssysteem. Maar zij werd ook weer niet resoluut en in elk opzicht doorkruist ${ }^{64}$. Omgekeerd was ook bij Churchill geen sprake van een even ongegeneerde en onsentimentele koehandelsmentaliteit als bij Stalin ${ }^{65}$. Alleen al, omdat Churchills positie en het Engelse regeringsstelsel zo totaal anders waren. Nogmaals, we zullen geen antwoord kunnen geven op de vraag of alle conflicten bij een consequente verdelingspolitiek vermeden hadden kunnen worden. We kunnen wél zeggen, dat het Westerse denken en handelen op verschillende golflengten - een pragmatisch-machtspolitieke én een universalistische - in hoge mate verantwoordelijk zijn voor vele onduidelijkheden in de wederzijdse afspraken en verwachtingen. Daardoor kon de Sovjet-Unie zeer wel de indruk krijgen, dat het Westen haar met de universalistische hand trachtte te ontfutselen, wat het haar met de pragmatische hand had toegestaan.

Omgekeerd vloeiden uit dit dooreenlopen van pragmatisme en universalisme ook voor de politici van het Westen zelf de nodige teleurstellingen en angsten voort. De waarschuwingen voor het Russische optreden en de Russische toekomstbedoelingen, die Harriman en Kennan al spoedig na Jalta uit Moskou doorseinden en die op de nieuwe Amerikaanse leiders zo veel indruk maakten, resulteren toch tenslotte ook uit het gevoel van ontgoocheling, dat de Sovjet-Unie zo weinig met het democratische patroon overeenkwam. En het was die ontgoocheling, die de nieuwe garnituur na Roosevelts dood tot een andere stijl en aanpak bracht. Een stijl en aanpak, die zij zelf en heel het Westen vrijwel als logische reactie zagen op de politiek van het Kremlin, die echter weer voortvloeide uit de militaire rol-

64. Niet alleen kwamen de Amerikanen onophoudelijk in conflict met dat universalisme door het feit, dat de militaire leiding unilaterale maatregelen moest nemen, die in het geval van Italië en Frankrijk tevens duidelijk een politiek karakter droegen. Daarnaast was er de Amerikaanse Monroetraditie, dat het Westelijk halfrond en nu ook de Pacific gebieden waren, die bij uitsluiting onder verantwoordelijkheid van de v.s. vielen. Men kan dus stellen, dat een politiek van verdeling van invloedssferen juist in Amerika een uitgesproken traditie was. Toch sluit dat niet uit, dat de Amerikanen zelf dit weliswaar erkenden, maar tevens als onvermijdelijk voorstadium of middel aanzagen om het gewenste mondiale universalisme te kunnen verwezenlijken, in dezelfde geest als zij oorlog voerden om een einde te maken aan die oorlog. 65. Stalin offreerden de Engelsen bijv. blijvende bruggehoofden in West-Europa, zoals België en Nederland. 
verdeling en die het Westen zelf, zij het met allerlei vage reserves, had gesanctioneerd. Gezien al die onduidelijkheden en dat dooreenlopen van universalisme en machtspolitiek, ook al onder Roosevelt,en gezien het feit, dat hij de tegenstellingen meer versluierde dan werkelijk vermocht op te lossen, lijkt mij de scherpe caesuur, die sommigen van zijn dood willen maken, onhoudbaar ${ }^{66}$. Evenmin als men kan stellen, dat Roosevelt Oost-Europa geheel of gedeeltelijk aan de Russische invloed had kunnen onttrekken, evenmin kan men, op grond van hedendaagse aspiraties, volhouden, dat zijn opvolgers een echte kans op coöperatie hebben gemist. Die kans was er uitsluitend bij volmondige aanvaarding van het feit, dat de Sovjet-Unie het leeuwedeel van de strijd tegen het nazisme was toegevallen en dat het Rode Leger Oost-Europa had veroverd. Maar die volmondige aanvaarding was weer in strijd met de Amerikaanse traditie en beginselen niet alleen, maar met de traditie en beginselen van heel het Westen, die zojuist uit alle macht tegen Hitler waren gemobiliseerd.

Daarmee zijn we terug, nog eenmaal, bij de neo-pragmatici. Men kan met Halle, Morgenthau en anderen wel opmerken, dat het ideologische denken een puur pragmatische benadering vertroebelde. Men moet toch de vraag stellen, of dit anders mogelijk was en hoe het kwam. De polariteit tussen machtspolitiek en ideologie, die Halle opstelt, is namelijk vrij theoretisch, omdat het twee verschillende grootheden betreft, die altijd samenhangen, zoals vorm en inhoud. Ideologie vormt het richtsnoer en denkraam of ook de inspiratiebron, volgens welke machtspolitiek wordt bedreven. Machtspolitiek staat altijd in dienst van iets. Ook de pragmaticus is ideoloog. Wanneer die 'ideologie' echter de status-quo wil handhaven, treedt zij minder naar voren, dan wanneer zij op een verandering uit is. Perioden van grote verschuivingen lijken daarom meer ideologisch gekleurd dan perioden van stabiliteit.

Het neo-pragmatisme is dan ook zelf uitvloeisel van een in menig opzicht statische constellatie. De puur pragmatische benadering, die men retrospectief misschien de staatslieden van 1945 wil aanbevelen, was echter toen onmogelijk. In het klimaat, dat allerwegen opgeroepen werd door een gigantische worsteling tegen een totalitair systeem, zou een nuchtere koehandel in de geest van Stalin een ondragelijk cynisme hebben betekend. Zelfs Churchill, bij al zijn realisme en vertrouwdheid met balance-of-power-denken, kon zich dan wel schikken in het onvermijdelijke, dat het Rode Leger Polen zou bevrijden, zijn oude afkeer van het communisme maakte hem die pragmatische aanpak ook weer zo zwaar, dat hij tegelijkertijd als een der eersten met al zijn oratorisch geweld het visioen van een demonisch Rus-

66. Ook van Roosevelt zijn er uitlatingen uit zijn laatste weken, die zijn onverholen teleurstellingen onthullen over de Russische uitleg van Jalta. Overigens geen bewijs van een Russische vertrouwensbreuk, maar eerder van de diepgaande communicatiestoring en het denken op verschillende golflengtes. Zie ook noot 11 . 
land opriep, dat klaar stond, om de hele vrije wereld naar de keel te vliegen. Onze huidige vertrouwdheid met de status-quo mag ons niet doen vergeten, dat er ook nog een verschil is tussen het Rusland van het Kosigin-Bresnjew-regime en dat van Josef Stalin. Van het Westen te verlangen, dat het in 1945 alle hoop op een democratische ontwikkeling in Westelijke zin voor Oost-Europa bij voorbaat zou hebben afgeschreven is, nogmaals, verlangen, dat het essentiële eigen tradities zou hebben verloochend op het moment, dat die tradities een ontzagwekkende vuurproef hadden doorstaan. Alleen dient dan de historicus van de koude oorlog wél te bedenken, dat het juist die hoop was - het uitvloeisel van de wens om Europa en de wereld naar Westers patroon te modelleren - die voor de Sovjet-Unie een bedreiging vormde. De machtspolitieke tegenstellingen zijn daarom niet los te denken van de maatschappijopvatting, die er achter stond. Zelfs Stalin, de meest nuchtere pragmaticus van de macht uit onze eeuw, kon niet uit onder het feit, dat het nationaal-russische belang onlosmakelijk vast zat aan de leninistische leer en aan alle communistische bewegingen ter aarde, ook als hij dat in stilte misschien eens verwenst mag hebben.

Het blijft de onmiskenbare verdienste van de revisionisten, dat zij het oude zwart-wit-schema hebben omgegooid en ons de ogen geopend hebben voor de talrijke machtspolitieke ingrediënten in het Amerikaanse universalisme, waardoor tal van Russische reacties begrijpelijk worden. Door de Sovjet-Unie en het Stalinistische bewind echter stilzwijgend te nemen voor wat het was, zoals men een strenge winter neemt, zijn zij blind voor de ideeële kant van het Amerikaanse universalisme. In dat onnoemelijk complexe geheel van de Amerikaanse politiek storten zij zich uitsluitend op de machtspolitieke facetten. Noch de drang naar vrije markten, noch de wil om het communisme overal in te dammen, noch de wens om de wereld volgens eigen beeld te hervormen, noch de eis de Amerikaanse belangen boven al veilig te stellen, noch de verontrusting over de methoden van het Stalinisme, noch het geloof in Amerika's zending om de mensheid gelukkig te maken vormden dé motor van alle beslissingen. Het was een onophoudelijke wisseling en vermenging, in telkens andere samenstelling, van al deze elementen samen.

Het is goed om te eindigen bij het begin: con sordino. Vooral, omdat zeer veel, van wat voor de v.s. geldt ook voor West-Europa geldt. Bovendien ontbreekt in de Sovjet-Unie nog altijd een geschiedschrijving die zich ook maar in de verste verte zou kunnen meten met de hier geschetste Amerikaanse.

Een kort slotoordeel op dit ogenblik zou een wat goedkope concessie zijn aan de onuitroeibare behoefte aan cijfers en formules. Het bezwaar van de revisionistische benadering is juist, dat zij de oude cijfers door nieuwe vervangt. En die gaan er bij de bijna fysieke formulehonger van velen vandaag in als koek. Maar de historicus, die in een schematoloog verandert, spijkert daarmee de toegang dicht tot datgene, wat hij juist bezig is te zoeken: de realiteit. 


\title{
Het Van der Meulen - archief ca.*
}

\author{
J. H. KERNKAMP
}

'Die Firmenarchive eröffnen den Zugang zum gestaltenden Menschen', tot deze slotsom komt prof. dr. Hermann Kellenbenz in een belangwekkend overzicht van 'Firmenarchive und ihre Bedeutung für die europaische Wirtschafts- und Sozialgeschichte'. Het Nederlandse koopmansarchief van Daniël van der Meulen "cum annexis" ontbreekt weliswaar in zijn verhaal, maar de Keulse hoogleraar weet van het bestaan af en wenst gaarne nadere bijzonderheden te vernemen, zoals is gebleken bij de Amsterdamse jaarvergadering van de Hansischer Geschichtsverein. Het ligt thans in de bedoeling een en ander over dit archief en aanverwante archivalia mede te delen ${ }^{1}$.

Het betreft hier in de eerste plaats het omvangrijke archief van de Antwerpse koopman Daniël van der Meulen zelf, die bij het verlies van de Scheldestad aan de Spanjaarden, in 1585, na een kortstondig verblijf te Haarlem en Delft, uitwijkt naar Bremen om in 1591 naar Holland terug te keren en zich in Leiden te vestigen, waar hij in 1600 op nog betrekkelijk jonge leeftijd aan pest overlijdt.

Als we bedenken dat Daniël 45 jaar oud is geworden, komen we onder de indruk van de activiteiten van hem en zijn correspondenten bij het constateren, dat zijn archief 11472 stukken bevat, voornamelijk brieven en rekeningen.

In 1929 had mr. J. W. Verburgt de inventarisatie van de collectie, bewaard in het Gemeente-archief te Leiden, voltooid en daarmee de aandacht op deze rijke bron voor de economische en sociale geschiedenis gevestigd. Het zou tot 1935 duren eer een uitgave werd overwogen en wel door het Historisch Genootschap te Utrecht. Van die tijd dateert een ontwerp van wijlen prof. dr. Z. W. Sneller met een selectie van bescheiden inzake de overiand- en overzeehandel. Deze opzet bleek niet te verwezenlijken, omdat de meeste brieven te veel onderwerpen tegelijkertijd behandelden. Zolang er geen vaste bewerker gevonden was, bleef het bij vage aanduidingen in de jaarverslagen vóór de Tweede Wereldoorlog van het H.G. Eerst toen de keuze op wijlen dr. J. C. Westermann gevallen was, namen de plannen in 1940 vastere vorm aan. Als medewerkster-copiiste werd wijlen mej. dr. M. Simon Thomas aangesteld. De handelsbrieven zouden het eerst aan bod

* Tekst van een afscheidscollege gegeven op 14 november 1969 bij het aftreden als gewoon hoogleraar in de economische en sociale geschiedenis aan de Rijksuniversiteit te Utrecht.

1. In: Zeitschrift für Firmengeschichte und Unternehmerbiografie, XIV, nr. 1 (1969), 19. 